\title{
Radiation therapy and PD-1/PD-L1 blockade: the clinical development of an evolving anticancer combination
}

\author{
Jun Gong ${ }^{1}$, Thang Q. Le ${ }^{2}$, Erminia Massarelli ${ }^{1}$, Andrew E. Hendifar ${ }^{3}$ and Richard Tuli ${ }^{4^{*}}$
}

\begin{abstract}
Several inhibitors of programmed cell death-1 (PD-1) and programmed death ligand-1 (PD-L1) have been approved as a form of immunotherapy for multiple cancers. lonizing radiation therapy (RT) has been shown to enhance the priming and effector phases of the antitumor T-cell response rendering it an attractive therapy to combine with PD-1/PD-L1 inhibitors. Preclinical data support the rational combination of the 2 modalities and has paved way for the clinical development of the combination across a spectrum of cancers. In this review, we highlight the preclinical and clinical development of combined RT and PD-1/PD-L1 blockade to date. In addition to a comprehensive evaluation of available safety and efficacy data, we discuss important points of consideration in clinical trial design for this promising combination.
\end{abstract}

Keywords: Radiation therapy, PD-1, PD-L1, Clinical trials, Preclinical, Antitumor, Immune response, Checkpoint inhibitor

\section{Background}

Early preclinical evidence demonstrated that activation of the programmed cell death 1 (PD-1) and programmed death ligand 1 (PD-L1) axis suppressed the activation and proliferation of tumor antigen-specific T-cells and promoted tumorigenesis $[1,2]$. These processes were reversed with PD-1/PD-L1 blockade and supported the concept of PD-1/PD-L1 blockade as a potential form of anti-cancer immunotherapy. The first agents in the family of PD-1/PD-L1 inhibitors to be approved by the Food and Drug Administration (FDA) were the humanized monoclonal IgG4 antibodies, pembrolizumab and nivolumab, that targeted PD-1 in unresectable or advanced melanoma [3-10]. There are currently 5 PD-1/PD-L1 inhibitors approved by the FDA for the treatment of a number of solid tumors and hematologic malignancies [11-43].

Ionizing radiation therapy (RT) is widely used in the definitive and metastatic setting for local tumor control; however, the ability of radiation to elicit a systemic

\footnotetext{
* Correspondence: richard.tuli@cshs.org

${ }^{4}$ Departments of Radiation Oncology and Biomedical Sciences, Samuel Oschin Comprehensive Cancer Institute, Cedars-Sinai Medical Center, 8700 Beverly Blvd, AC 1023, Los Angeles, CA 90048, USA

Full list of author information is available at the end of the article
}

tumor response with associated regression of untreated metastases outside of the radiation field has been reported and was first described as the abscopal effect [44]. Increasing evidence supports that the abscopal effect is likely immune-mediated - largely, in a T-cell dependent manner with a complex interplay between proimmunogenic and proinflammatory factors [45-53]. Over time, recognition of the immunomodulatory properties of radiation has led to the integration of RT with immune-modulating agents including immune checkpoint inhibitors to potentially develop a combination therapy with enhanced or synergistic anticancer activity (Fig. 1).

Indeed, an initial preclinical study showed that combining RT (1-2 fractions of 12 Gray (Gy) to the primary tumor) with an anti-cytotoxic $\mathrm{T}$ lymphocyte-associated antigen-4 (CTLA-4) monoclonal antibody resulted in synergistic antitumor activity in a poorly immunogenic metastatic mammary carcinoma mouse model when CTLA-4 blockade by itself was ineffective [54]. Enhanced antitumor responses have also been observed across several preclinical animal models treated with combined RT and CTLA-4 blockade [55-58]. Since the first preclinical studies that highlighted the synergistic antitumor activity of combination RT and CTLA-4 


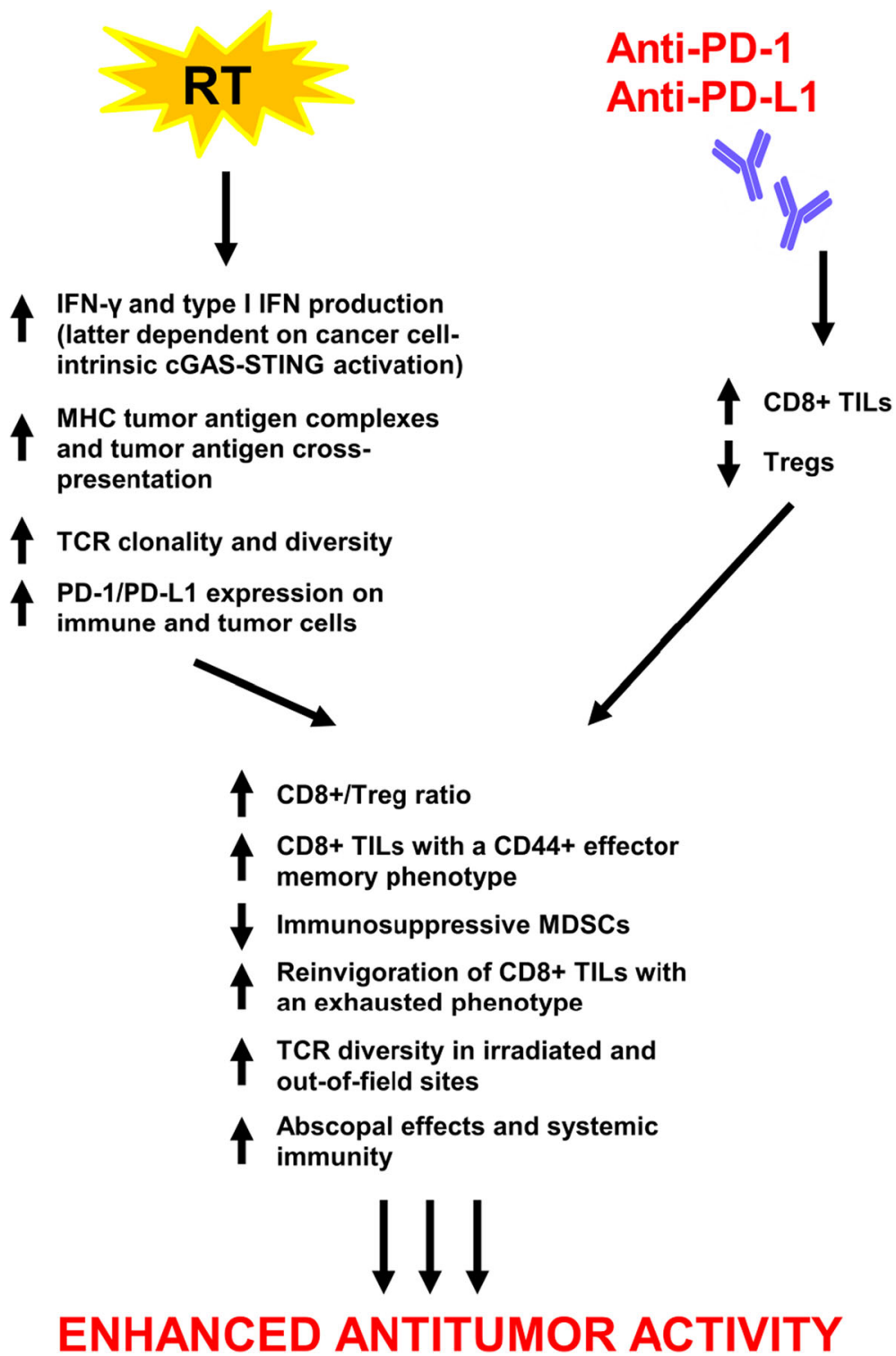

Fig. 1 Proposed mechanisms of synergy between RT and PD-1/PD-L1 inhibitors. Emerging evidence demonstrates that immune modulation from PD-1/PD-L1 inhibitors and RT through nonredundant pathways contributes to synergistic antitumor activity, thereby forming the basis for the rationale combination of the two modalities. RT, radiation therapy; PD-1, programmed cell death 1 receptor; PD-L1, programmed death ligand 1; IFN- $\gamma$, interferon- $\gamma$; CGAS, cyclic GMP-AMP (cGAMP) synthase; STING, stimulator of interferon genes; MHC, major histocompatibility complex; TCR, T-cell receptor; TILs, tumor-infiltrating lymphocytes, Tregs; regulatory T cells; MDSCs, myeloid-derived suppressor cells

blockade, several prospective clinical trials have reported on the activity of RT and ipilimumab in advanced solid tumors [59-66]. Similarly, there are numerous ongoing clinical trials investigating the combination of RT and CTLA-4 blockade that have been extensively reviewed and are beyond the scope of this manuscript $[67,68]$. Herein, we review in detail the preclinical and clinical development of the combination of RT and PD-1/PD-L1 inhibitors in cancer therapy.

\section{Preclinical studies}

The efficacy of combination RT and checkpoint blockade is associated with modulation of immune parameters within the tumor microenvironment

Early investigations in mouse models of solid and hematologic malignancies showed enhanced antitumor effects when treated with PD-1 or PD-L1 blockade in combination with in-field RT, sublethal total body irradiation (TBI), or stereotactic radiosurgery (SRS) compared to single modality treatment (Table 1) [69-85]. 
Table 1 Preclinical studies demonstrating antitumor activity of combined radiation therapy and PD-1/PD-L1 blockade

\begin{tabular}{lll}
\hline Cell line & Experimental model & RT dose \\
\hline B16-D5 (melanoma) & Mice subcutaneous & $\begin{array}{l}\text { TBI } 600 \text { cGy } \\
\text { (1 fraction) }\end{array}$ \\
& & \\
& & \\
$\begin{array}{l}\text { AT.3 (triple-negative } \\
\text { mammary) }\end{array}$ & Mice xenograft & 12 Gy (1 fraction) or \\
& & $4-5$ Gy (4 fractions) \\
GL261 (glioma) & Mice xenograft & 10 Gy (1 fraction) \\
$\begin{array}{l}\text { B16-SIY (melanoma) TUBO } \\
\text { (mammary) }\end{array}$ & Mice subcutaneous & 25 Gy (2 fractions) \\
$\begin{array}{l}\text { 5 T33 (myeloma) } \\
\text { A20 (B-cell lymphoma) } \\
\text { C1498 (leukemia) }\end{array}$ & 15 Gy (1 fraction) \\
5 T33 (myeloma) & Mice intravenous & TBI 500 cGy \\
& & Traction) \\
& Mice intravenous & TBI 1100 cGy \\
& &
\end{tabular}

$\begin{array}{ll}5 \text { T33 (myeloma) } \quad \text { Mice intravenous } & \text { TBI } 500 \text { cGy } \\ & \text { (1 fraction) }\end{array}$

CT26 (colon 4434 (BRAF ${ }^{\mathrm{V} 600 \mathrm{E}_{-}}$
mutant melanoma)
$4 \mathrm{~T} 1$ (triple-negative
mammary)
TUBO (mammary)
MC38 (colon
TSA (mammary)

B16-OVA (melanoma)
RENCA (renal)
B16-OVA (melanoma)
4 T1-HA (mammary)
PYMT (mammary)

B16-F10 (melanoma)

Meer (head and neck squamous)

Adeno-Cre viral vector (lung)

MB49 (bladder)

MC38 (colon

4 T1 (mammary) B16F10-OVA (melanoma)
Mice subcutaneous $\quad 10$ Gy (5 fractions)

Mice subcutaneous

12 Gy (1 fraction)

Mice subcutaneous

24 Gy (3 fractions)

Mice subcutaneous

15 Gy (1 fraction)

Mice subcutaneous

12 Gy (1 fraction)

Mice subcutaneous

12 Gy (1 fraction)

Mice subcutaneous

20 Gy (1 fraction)

Mice subcutaneous

1, 6, 10 Gy fractions

GEMM intrathoracic injection

8.5 Gy twice daily over 2 days

Mice xenograft

12 Gy (1 fraction)

Mice subcutaneous

24 Gy (3 fractions)

PD-1/PD-L1 dose
PD-L1 mAb $20 \mathrm{mg} / \mathrm{kg}$ IP starting on
day 4 then every 3-4 days $+1 \times 10^{6}$
gp100 or OVA $257-264$ pulsed dendritic
cell vaccine SC on day 4 and $11 \pm$
$1 \times 10^{7}$ pmel T-cells (adoptive transfer)
IV on day 4 after inoculation

PD-1 mAb $100 \mu \mathrm{g}+$ CD137 mAb

$100 \mu \mathrm{IIP}$ on days $0,4,8$, and 12 of

$[70,71]$ RT

PD-1 mAb $10 \mathrm{mg} / \mathrm{kg}$ IP on days 10, 12 , and 14 of RT

PD-L1 mAb $200 \mu \mathrm{g}$ IP every 3 days for 4 doses starting 3 weeks after RT

PD-L1 mAb $200 \mu \mathrm{g}$ IP on days 12, 14, $17,19,21,26$, and 28 after inoculation

HSCT on day 0 + PD-L1 mAb $200 \mu \mathrm{g}$ IP on days $3,5,10,12,17$, and 19 after $\mathrm{HSCT} \pm$ vaccine (irradiated 5 T33 cells or 5 T33 cells transfected with empty vectors) on days 3,10 , and 17 after HSCT

PD-L1 mAb $200 \mu \mathrm{g}$ IP on days 12, 14, $17,19,21,26$, and 28 after inoculation \pm LAG-3, TIM-3, or CTLA4 mAbs $200 \mu \mathrm{g}$ IP on same days

PD-1 or PD-L1 mAb 10 mg/kg IP 3 times weekly up to 3 weeks starting on day 1 of RT

PD-L1 mAb $200 \mu \mathrm{g}$ IP every 3 days for 4 doses starting on day 0 or 1 of RT

PD-1 mAb (dose NR) starting on day 15 after inoculation and every 4 days thereafter

PD-1 mAb 10 mg/kg \pm CTLA-4 mAb $10 \mathrm{mg} / \mathrm{kg}$ IP on days $7,9,11,14$, and 16 following tumor cell inoculation

PD-1 mAb $200 \mu \mathrm{g}$ IP every 3 days for 3 doses starting 1 day prior to RT

PD-1 mAb dose NR + single dose of CTLA-4 mAb (dose NR) 3 days prior to PD-1 and RT

PD-L1 mAb $200 \mu \mathrm{g}+$ CTLA-4 mAb $200 \mu \mathrm{g}$ IP every 3 days for 3 doses starting 5 or 9 days after inoculation

PD-L1 antibody dose NR

PD-1 mAb $200 \mu \mathrm{g}$ IP 3 times weekly starting $6 \mathrm{~h}$ after second RT dose

PD-L1 mAb $250 \mu \mathrm{g}$ IP twice weekly for 4 doses starting 1 day prior to RT

PD-1 mAb \pm CD137 mAb 5-10 mg/ $\mathrm{kg}$ IP on days 13,15 , and 17 after 
Table 1 Preclinical studies demonstrating antitumor activity of combined radiation therapy and PD-1/PD-L1 blockade (Continued)

\begin{tabular}{|c|c|c|c|c|}
\hline Cell line & Experimental model & RT dose & PD-1/PD-L1 dose & Ref. \\
\hline $\begin{array}{l}\text { 4-hydroxytamoxifen } \\
\text { induction (BRAF-mutant, } \\
\text { PTEN-deficient melanoma) }\end{array}$ & $\begin{array}{l}\text { GEMM topical } \\
\text { induction }\end{array}$ & 14 Gy (1 fraction) & $\begin{array}{l}\text { PD- } 1+\text { CD137 or PD- } 1+\text { CTLA- } 4 \text { mAb } \\
100 \mu \mathrm{g} \text { IP twice weekly for } 4 \text { doses } \\
\text { on day } 1 \text { of RT }\end{array}$ & [99] \\
\hline 344SQ (lung) & Mice subcutaneous & 36 Gy (3 fractions) & $\begin{array}{l}\text { PD-1 mAb } 10 \mathrm{mg} / \mathrm{kg} \text { IP starting on } \\
\text { day } 1 \text { of RT and continued for } \\
\text { additional 3-4 doses }\end{array}$ & [91] \\
\hline ARK (esophageal squamous) & Mice subcutaneous & 20 Gy (10 fractions) & $\begin{array}{l}\text { PD- } 1 \text { mAb (dose NR) starting } 2 \text { days } \\
\text { before RT and every } 3 \text { days } \\
\text { thereafter } \pm \text { carboplatin and } \\
\text { paclitaxel IP (dose NR) on day } 1 \text { of } \\
\text { RT and every } 3 \text { fractions }\end{array}$ & [85] \\
\hline GL261 (glioma) & Mice xenograft & 10 Gy (1 fraction) & $\begin{array}{l}\text { PD-1 mAb } 200 \mu \mathrm{g} I \mathrm{P} \text { on days } 10,12, \\
\text { and } 14 \text { of RT } \pm \text { TIM-3 mAb } 250 \mu \mathrm{g} I \mathrm{P} \\
\text { days } 7,11 \text {, and } 15 \text { of RT }\end{array}$ & [90] \\
\hline $\begin{array}{l}\text { CT26 (colon } 4434 \text { (BRAF } F^{\mathrm{V} 600 \mathrm{E}_{-}} \\
\text {mutant melanoma) }\end{array}$ & Mice subcutaneous & 10 Gy (5 fractions) & $\begin{array}{l}\text { PD- } 1 \text { or PD-L } 1 \text { mAb } 10 \mathrm{mg} / \mathrm{kg} \text { IP } 3 \\
\text { times weekly for } 1 \text { week starting on } \\
\text { day } 1 \text { of RT }\end{array}$ & [88] \\
\hline TSA (mammary) & Mice subcutaneous & $\begin{array}{l}24 \text { Gy ( } 3 \text { fractions) on } \\
\text { days } 12,13 \text { and } 14 \\
\text { after inoculation }\end{array}$ & $\begin{array}{l}\text { PD-1 mAb } 200 \mu \mathrm{g} \text { IP on days 12, 15, } \\
19,22 \text { and } 26 \text { after inoculation }\end{array}$ & [89] \\
\hline Hep-55.1c (hepatocellular) & Mice orthotopic & 30 Gy (3 fractions) & $\begin{array}{l}\text { PD-1 mAb } 250 \mu \mathrm{g} \text { IP on days } 7,14 \\
\text { and } 21 \text { after inoculation }\end{array}$ & [96] \\
\hline KPC and Pan02 (pancreatic) & Mice subcutaneous & $\begin{array}{l}\text { 6, 12, or } 20 \text { Gy } \\
\text { ( } 1 \text { fraction) } \\
10 \text { Gy (5 fractions) } \\
15 \text { Gy (5 fractions) }\end{array}$ & $\begin{array}{l}\text { PD-L1 mAb } 10 \mathrm{mg} / \mathrm{kg} \text { IP on days } 4 \text {, } \\
7,10 \text {, and } 13 \text { after inoculation + } \\
\text { gemcitabine } 100 \mathrm{mg} / \mathrm{kg} \mathrm{IP} \text { on days } 0 \\
\text { and } 3 \text { of inoculation }\end{array}$ & [95] \\
\hline HCa-1 (hepatocellular) & Mice intramuscular & 10 Gy (1 fraction) & $\begin{array}{l}\text { PD-L1 mAb } 10 \mathrm{mg} / \mathrm{kg} \text { IP every } \\
3 \text { days for } 4 \text { doses starting on day } 1 \\
\text { of RT }\end{array}$ & [97] \\
\hline LM8 (osteosarcoma) & Mice subcutaneous & 10 Gy (1 fraction) & $\begin{array}{l}\text { PD-L1 mAb } 150 \mu \mathrm{g}+\text { CTLA-4 mAb } \\
150 \mu \mathrm{g} \text { IP every } 3 \text { days for } 3 \text { doses } \\
\text { starting on days 9, 12, and } 15 \text { after } \\
\text { inoculation }\end{array}$ & [98] \\
\hline CT26 (colon & Mice intradermal & $\begin{array}{l}\text { RFA 17-gauge single } \\
\text { ablation electrode for } \\
3.5-4.5 \text { min at target } \\
\text { temperature of } 70 \\
\text { degrees } C\end{array}$ & $\begin{array}{l}\text { PD-1 mAb } 200 \mu \mathrm{g} \text { IP every } 3 \text { days for } \\
4 \text { doses }\end{array}$ & [94] \\
\hline
\end{tabular}

$R T$ radiation therapy, $T B I$ total body irradiation, $c G y$ centigray $m A b$ monoclonal antibody, IP intraperitoneal, SC subcutaneous, $I V$ intravenous, Gy Gray, HSCT hematopoietic stem cell transplantation, LAG-3 lymphocyte-activation gene 3, TIM-3 T-cell immunoglobulin mucin-3, NR not reported, GEMM genetically engineered mouse model, RFA radiofrequency ablation

Combined modality therapy was associated with higher levels of $\mathrm{CD} 8+/$ interferon- $\gamma \quad(\mathrm{IFN} \gamma)+/$ tumor necrosis factor- $\alpha(\mathrm{TNF} \alpha)+$ cytotoxic T-cells, increased PD-1, T-cell immunoglobulin mucin-3 (TIM-3), lymphocyte-activation gene 3 (LAG-3), and 2B4 (immune checkpoints) expression on $\mathrm{CD} 8+\mathrm{T}$-cells, decreased numbers of $\mathrm{CD} 4$ +/FOXP3+ regulatory T-cells (Tregs) and myeloid-derived suppressor cells (MDSCs), upregulation of PD-L1 on dendritic cells and tumor cells in irradiated tumors, RT-induced upregulation of major histocompatibility complex (MHC) class I tumor-associated antigen complexes, and enhanced antigen cross-presentation in draining lymph nodes compared to single modality arms [71, 72, 74, 76-79].

\section{Combination modality-induced immune profile changes may be time-dependent}

Early syngeneic mouse tumor models demonstrating significant improvements in survival and tumor volume reduction with the combination of $\mathrm{RT}$ and $\mathrm{PD}-1$ or PD-L1 blockade compared to single modality and control arms identified elevations in tumor cell PD-L1 expression that were $\mathrm{CD} 8+\mathrm{T}$-cell and IFN $\gamma$-dependent following irradiation (10 Gy over 5 daily fractions) compared to non-irradiated mice with peak levels occurring $72 \mathrm{~h}$ after last dose of RT [86]. RT-induced increases in the CD8+/Treg ratio and PD-L1 expression occurred 24-96 $\mathrm{h}$ post-RT in a separate mouse model [81]. In colon carcinoma tumors, the addition of PD-L1 
blockade on day 1 of RT (schedule A), day 5 of RT (schedule B), or 7 days after RT (schedule C) showed that there was no significant difference in overall survival $(\mathrm{OS})$ between schedule $\mathrm{A}$ and $\mathrm{B}(p>0.05)$ though sequential therapy (schedule $C$ ) was ineffective in enhancing OS compared to RT alone (median OS 30 days vs. 35 days, $p>0.05$ ) [86]. Notably, PD-1 expression was significantly decreased on CD8+ T-cells 7 days after RT compared to time-matched controls $(p<0.05)$.

\section{Abscopal effects and systemic immunity}

On subcutaneous tumor flank rechallenge of treatment-naïve mice and mice cured by combination RT and checkpoint blockade, immunologic memory was established in cured mice but not in treatment-naïve mice suggesting that the immune system in cured mice retained the ability to recognize tumor-associated antigens and mount an immune response of greater magnitude and speed upon rechallenge, i.e., systemic immunity [71, 72]. Abscopal effects have been shown to be mediated, in part, by PD-1 as administration of a single fraction of 15 Gy by stereotactic ablative radiotherapy (SABR) to the primary tumor in a melanoma subcutaneous mouse model resulted in significant reduction in tumor volumes of secondary nonirradiated tumors in PD-1-knockout mice compared to PD-1-wild-type (WT) mice [87]. Addition of a PD-1 inhibitor to SABR resulted in synergistic antitumor activity on the primary tumor compared to PD-1 inhibitor or SABR alone and recapitulated abscopal effects on secondary nonirradiated tumors in PD-1-WT mice when treatment alone with anti-PD-1 or SABR did not reduce secondary tumor growth. Furthermore, following RT, higher levels of PD- $1+$ CD11a ${ }^{\text {high }}$ CD8 + T-cells were seen in primary tumors compared to secondary tumors and higher levels in irradiated compared to nonirradiated tumors; this population of cells appeared to comprise the principal tumor-specific reactive phenotype. This latter finding has been confirmed in another study where RT increased T-cell receptor (TCR) repertoire clonality and diversity of the TCR repertoire in irradiated tumors compared to controls, however, the addition of PD-1 inhibition to RT increased TCR diversity both in irradiated and out-of-field sites [88]. Further analysis revealed that most of these TCR clones arose from progenitor clones that were established in tumors prior to therapy, and it is the influx of tumor-infiltrating lymphocytes (TILs) from outside the tumor along with resident-tumor infiltrating $\mathrm{T}$-cells that contribute to the enhanced tumor responses seen with combination therapy.

Recently, durable regression of irradiated tumors and abscopal responses observed in mammary tumor-bearing mouse models treated with combination RT and checkpoint blockade were shown to be dependent on cancer cell-intrinsic activation of the type I IFN pathway as mediated by cyclic GMP-AMP (cGAMP) synthase (cGAS) and stimulator of interferon genes (STING) signaling [89]. RT-induced abscopal responses with PD-1 blockade were additionally shown to be regulated by Trex 1 where induction of Trex1 expression in cancer cells resulted in loss of abscopal responses in mice treated with the combination.

\section{Combined modality therapy reverses T-cell exhaustion and resistance to $\mathrm{RT}$ and anti-PD-1 therapy}

Murine tumor xenografts have shown that increasing levels of PD-1 and TIM-3 co-expression in CD4+ T-cells, CD8+ T-cells, and Tregs over time contribute to an exhausted or impaired T-cell phenotype [90]. Furthermore, resistance to anti-PD-1 therapy in RT-refractory tumors has been characterized by significant elevations in expression of genes associated with T-cell exhaustion, increased levels of checkpoints including LAG-3, TIM3, and CTLA-4 on CD4+ T-cells, and decreased number of CD11c + tumor-associated macrophages (TAMs) [81]. The addition of immune checkpoint inhibitors to RT has been shown to enhance tumor response compared to controls across several mouse tumor models through reinvigoration of exhausted CD8+ TILs characterized by increased Ki67+ GzmB+ T-cells within the exhausted PD-1+ Eomes+ T-cell pool, increased CD8+ CD44+ TILs, and increased CD8+/Treg ratio [61, 77, 85].

Moreover, an anti-PD-1-resistant murine lung cancer model established through sequential in vivo passage of nonresponsive tumors to ongoing anti-PD-1 therapy was characterized by significant downregulation of MHC class I and II genes including $\beta 2$-microglobulin and reduction in $\mathrm{CD} 4+/ \mathrm{CD} 8+$ TILs and IFN- $\gamma$ production in resistant tumors compared to parental tumors [91]. Addition of RT induced IFN- $\gamma$ production and MHC class I expression and ultimately restored response to PD-1 blockade in resistant tumors. Addition of a PD-L1 inhibitor has been shown to reverse RT-induced tumor equilibrium in favor of tumor regression in mice subcutaneously injected with melanoma and breast tumors demonstrating RT-induced stable disease (SD, defined as $\geq 3$ weeks) characterized by a transient rise and fall in levels of tumor-infiltrating CD8+ T-cells and IFNY [92]. Extrinsic RT resistance has been recently shown to be contributed by RT-induced host STING activation resulting in immunosuppressive MDSC recruitment that is mediated by chemokine receptor type 2 (CCR2) in a syngeneic mouse model of colon carcinoma [93]. Treatment with anti-CCR2 antibodies could potentially serve a role in reversing RT resistance by attenuating host STING-mediated immunosuppression and complement $\mathrm{RT}$ and checkpoint blockade combinations. 
A growing body of preclinical evidence supports the combination of other immunotherapeutic agents with RT or radiofrequency ablation (RFA), immune checkpoint blockade, and/or chemotherapy to enhance tumor growth control (and often systemic control)in preclinical mouse models; synergistic antitumor activity with multimodality therapy was characterized by tumor cell PD-L1 expression in a JAK/Stat1-dependent manner and reduced numbers of CD11b + Gr1+ cells (MDSCs) [90, 94-99].

\section{Toxicities}

Several preclinical studies have investigated the toxicity of combined RT and checkpoint blockade. Notably, one investigation of lung-irradiated (20 Gy) C57bl/6-WT mice receiving anti-PD-1 antibody $(10 \mathrm{mg} / \mathrm{kg}$ intraperitoneal twice per week for 5 doses) showed more findings of abnormal alveoli, inflammatory changes, and exudates in the alveolar septa associated with a 2.1-fold increase in CD8+ T-cells in the irradiated lung tissues of mice in the RT and PD-1 blockade arm though post-RT mortality up to 120 days was not significantly different in the RT alone vs. RT and PD-1 blockade arm $(p=0.657)$ [100]. A separate study, however, using a similar dose of 20 Gy of thoracic RT (designed to induce mortality) to C57bl/6 mice identified worse survival with RT and PD-1 blockade (36\% survived) than RT alone $(70 \%$ survived, $p=0.0169)$ at 21 days post-RT and increased T-cell infiltrates in lung and cardiac tissues (both inand out-of-field) of mice treated with RT and PD-1 blockade compared to RT alone putatively due to enhanced healthy tissue damage by T-cell activation with the addition of PD-1 blockade to thoracic RT [101]. Incorporating PD-1 blockade to cardiac RT in mice has also shown to decrease survival and exacerbate cardiac dysfunction and myocarditis that are CD8+ T-cell-mediated [102].

\section{Clinical studies}

\section{Retrospective studies}

Numerous case reports and case series have documented clinically significant, and often durable, tumor responses to the combination of RT and PD-1/PD-L1 blockade in advanced or metastatic melanoma, NSCLC, Hodgkin lymphoma, RCC, and cervical cancer [103-112]. Initial retrospective series of patients with melanoma brain metastases treated with SRS or fractionated RT within 3-6 months of receiving anti-PD-1 therapy produced promising 1-year OS rates and significantly improved 6and 12-month distant brain metastasis control and OS rates in those treated with SRS and anti-PD-1 therapy vs. SRS and chemotherapy (Table 2) [113, 114]. In 24 patients with brain metastases from melanoma (54\%) and NSCLC (46\%), treatment with SRS before, during, or after PD-1 blockade produced 6- and 12-month median OS rates of 85 and 78\%, respectively [115]. One retrospective study investigated 53 patients with metastatic melanoma treated with RT sequential or concurrent to anti-PD-1 therapy or as salvage therapy in the setting of progression on anti-PD-1 therapy (35 patients received extracranial RT or intracranial SRS and 21 patients received whole brain radiotherapy (WBRT)) and showed that median OS and ORR were not significantly different between concurrent and sequential RT/SRS cohorts (Table 2) [116].

A single-institute retrospective trial analyzed the efficacy of concurrent SRS and anti-PD-1 or anti-CTLA-4 therapy (defined as SRS within 4 weeks of administration of checkpoint inhibitors) in 75 patients with melanoma brain metastases and identified significantly improved median percent reduction in lesion volume with concurrent compared to nonconcurrent arms and with anti-PD- 1 compared to anti-CTLA- 4 arms at 3 months and 6 months [117]. However, when both anti-PD-1 and anti-CTLA-4 therapies were combined there was no significant difference in median OS between nonconcurrent (9.0 months, range 2.1-61.8) and concurrent arms (19.1 months, range 2.7-64.2, $p=0.0691)$. In solely metastatic NSCLC patients $(n=21)$, combined RT to oligoprogressive sites along with PD-1/PD-L1 blockade or other immune therapies resulted in excellent local control, median time to systemic progression of 2.3 months (95\% confidence interval (CI) 1.0-4.5), and median OS of 7.2 months (95\% CI 4.2-11.1) [118]. Among 25 patients with unresectable melanoma, abscopal responses (CR or PR) were observed in $56 \%$ of patients with the addition of late RT ( $>3$ months of insufficient response to anti-PD-1 monotherapy) [119].

A group of 137 patients with metastatic melanoma, NSCLC, and RCC treated with WBRT, SRS, or extracranial RT before or after initiation of PD-1 blockade experienced a median OS 249 days (8 months; interquartile range (IQR) 90-689) following the start of anti-PD-1 therapy though OS was 25.7 months in the cohort receiving brain RT as first form of palliative RT [120]. On multivariate analysis, melanoma patients fared best as the hazard ratio (HR) for death was 3.1 (95\% CI 1.7-5.9) for NSCLC and HR of 3.2 (95\% CI 1.2-7.9) for RCC compared to melanoma $(p=0.0008)$ possibly due to improved responses to checkpoint inhibitors in melanoma with the incorporation of both PD- 1 and CTLA- 4 inhibitors into standard care.

A secondary analysis of the phase I KEYNOTE-001 trial of 98 patients with locally advanced or metastatic NSCLC treated with pembrolizumab showed significantly improved median OS of 10.7 months $(95 \%$ CI $6.5-18.9)$ vs. 5.3 months (95\% CI $2.7-7.7$, HR $0.58,95 \%$ CI $0.36-0.94, p=0.026$ ) in those who ever did and did 
Table 2 Retrospective clinical studies with available results on the antitumor activity of combined radiation therapy and PD-1/PD-L1 blockade

\begin{tabular}{lllll}
\hline Study & $\mathrm{n}$ & Design & Outcomes & Toxicities \\
\hline RS & 26 & Melanoma BMs treated with SRS or & Median OS 11.8 mo (range 0.5-33.9) & 1 grade 2 headache relieved with \\
& & FSRT (16-30 Gy X 1-5 fractions) & and 1-year OS 55\% in unresected & steroids \\
& $\begin{array}{ll}\text { within 6 mo of nivolumab (1, 3, or } \\
\text { 10 mg/kg every 2 weeks for 12 }\end{array}$ & $\begin{array}{l}\text { BMs; median OS not reached and } \\
\text { doses then every 12 weeks for } 8\end{array}$ & 1-year OS 100\% in resected BMs &
\end{tabular}
doses)

RS $96 \quad$ Melanoma BMs treated with SRS (majority 24 Gy X 1 fraction) within 3 mo of nivolumab $3 \mathrm{mg} / \mathrm{kg}$ every 2 weeks, pembrolizumab $2 \mathrm{mg} / \mathrm{kg}$ every 3 weeks, or other systemic therapies

Melanoma and NSCLC BMs treated with SRS (median $20 \mathrm{~Gy} /$ fraction, IQR 16-21) within median 19 weeks (range 0-107) of nivolumab or pembrolizumab (median 5 cycles, IQR 3-6)

RS $53 \quad$ Metastatic melanoma treated with extracranial RT/intracranial SRS (830 Gy X 1-10 fractions) or WBRT (median 30 Gy X10 fractions) and pembrolizumab $2 \mathrm{mg} / \mathrm{kg}$ every 3 weeks or nivolumab 3 mg/kg every 2 weeks as concurrent, sequential, or salvage (following progression on anti-PD-1 therapy) therapy

RS $75 \quad$ Melanoma BMs treated with SRS (median 20 Gy, range 12-24 Gy) within \pm 4 weeks (concurrent) of pembrolizumab 2 or $10 \mathrm{mg} / \mathrm{kg}$ every 2-3 weeks or nivolumab $3 \mathrm{mg} / \mathrm{kg}$ every 2-3 weeks or ipilimumab

RS $21 \quad$ Metastatic NSCLC treated with RT (8-30 Gy X 1-10 fractions) while receiving anti-PD-1, anti-PD- $L 1$, and/or anti-CTLA-4, or other immune therapy

RS $25 \quad$ Unresectable melanoma treated with hypofractionated RT (1 weekly fraction over 4-5 weeks (84\%) or 1 gammaknife RT for BMs (16\%)) within 3 mo of anti-PD-1 (early) or > 3 mo after anti-PD-1 therapy (late)

RS 15 Metastatic melanoma, RCC, NSCLC treated with palliative RT (total 8-36 Gy via 3-8 Gy fractions) within \pm 75 days of PD-1 inhibitor

RS $84 \quad$ Metastatic melanoma, NSCLC, and other solid tumors treated with thoracic RT (median total dose 3000 cGy (range 600-7400 X 10 fractions) within 1 month (concurrent) or up 6 months (sequential) of PD-1/PD-L1 and/or CTLA-4 blockade
6- and 12-mo distant BM control rate 61\%/38\% anti-PD-1, 26\%/21\% anti-CTLA-4, 53\%/20\% BRAF/MEK inhibitor, 15\%/5\% chemotherapy ( $p=0.008) ; 6-$ and 12-mo OS 81\%/ $66 \%$ anti-PD-1, 84\%/50\% anti-CTLA-4, 83\%/75\% BRAF/MEK inhibitor, 70\%/15\% chemotherapy ( $p=0.004)$

6- and 12-mo OS 85 and 78\%; median OS not reached; 6- and $12-$ mo distant brain progression rate 37 and $65 \%$

Medians OS 6.4 vs. 8.6 mo ( $p=0.7672)$ for concurrent vs. sequential RT/SRS; ORR 31\% vs. 36\% $(p=1)$ for concurrent vs. sequential RT/SRS; lesional response rate $45 \%$ for 30 progressing lesions treated with salvage RT/SRS

Median \% lesion volume reduction at $3 \mathrm{mo}$ ( $-83.0 \%$ vs. $-52.8 \%$, $p<0.0001)$ and 6 mo (-94.9\% vs. $-66.2 \%, p<0.0001$ ) for concurrent vs. noncurrent; median \% lesion volume reduction at $3 \mathrm{mo}(-89.3 \%$ vs. $-66.2 \%, p<0.0001)$ and $6 \mathrm{mo}$ $(-95.1 \%$ vs. $-75.9 \%, p=0.0004)$ for anti-PD-1 vs. anti-CTLA-4

6- and 12-mo local control rates 91.7 and $85.2 \%$; median time to systemic progression 2.3 mo (95\% Cl 1.0-4.5); median OS 7.2 mo (95\% Cl 4.2-11.1)

$\mathrm{CR}, \mathrm{PR}, \mathrm{SD}$, and $\mathrm{PD}$ rates for radiated sites 24, 8, 44, and 28\% and for nonirradiated sites 29, 19, 19, and $33 \%$, respectively; abscopal responses (CR or PR) in 56\% for addition of late RT

Safety analysis

No significant differences in toxicity rates between PD-1/PD-L1 and CTLA-4 inhibitors or concurrent and sequential treatment
For anti-PD-1 therapy: 1 grade 2 headache managed with steroids

2 patients grade $\geq 3$ CNS toxicity: 1 seizure and 1 symptomatic radionecrosis requiring surgery

For RT arm: 3 patients grade $\geq 3$ rash, 1 grade $\geq 3$ diarrhea, 2 grade $\geq$ 3 radiation dermatitis, 1 grade $\geq 3$ radionecrosis; for WBRT arm: 1 grade $\geq 3$ nausea, 1 grade $\geq 3$ cognitive changes, 2 grade $\geq 3$ rash

NR

1 grade 4 cerebral edema (WBRT) and 1 grade 3 pneumonitis

No unusual AEs reported

All-grade immune-related AEs in 3 patients (20\%) and 1 RT-related AE (7\%) of moderate mucositis; no cases of pneumonitis

For all-grade AEs: 6 patients with pneumonitis (7.2\%, 1 grade $\geq 3)$; for grade $\geq 2$ AEs: 14 fatigue, 9 rash, 10 Gl toxicities, 12 infections, 8 thyroid dysfunction, 7 renal injury, and 9 other 
Table 2 Retrospective clinical studies with available results on the antitumor activity of combined radiation therapy and PD-1/PD-L1 blockade (Continued)

\begin{tabular}{|c|c|c|c|c|c|}
\hline Study & $n$ & Design & Outcomes & Toxicities & Ref. \\
\hline$\overline{\mathrm{RS}}$ & 29 & $\begin{array}{l}\text { Metastatic NSCLC treated with } \\
\text { thoracic RT (10-70 Gy X 1-35 } \\
\text { fractions) within } 6 \text { mo of PD-1/PD-L1 } \\
\text { and/or CTLA-4 blockade }\end{array}$ & $\begin{array}{l}\text { Median PFS and OS of } 3.8 \mathrm{mo}(95 \% \\
\mathrm{Cl} 1.9-8) \text { and } 9.2 \mathrm{mo}(95 \% \mathrm{Cl} 5.1-\text { not } \\
\text { reached) }\end{array}$ & $\begin{array}{l}\text { Possible treatment-related AEs: } 1 \\
\text { grade } 5 \text { pneumonitis and } 2 \text { grade } 3 \\
\text { pneumonitis }\end{array}$ & {$[125]$} \\
\hline RS & 133 & $\begin{array}{l}\text { Metastatic NSCLC, melanoma, and } \\
\text { RCC treated with palliative RT } \\
\text { (8-37.5 Gy X 1-15 fractions) within } \\
180 \text { days of PD- } 1 \text { or CTLA-4 inhibitor }\end{array}$ & $\begin{array}{l}\text { No significant difference in immune- } \\
\text { related AEs between those receiving } \\
\text { RT during/after checkpoint inhibitors } \\
\text { and before checkpoint inhibitors } \\
\text { ( } p=0.053) \text {, receiving RT within } \\
14 \text { days or outside } 14 \text { days of } \\
\text { checkpoint blockade ( } p=0.06) \text {, and } \\
\text { of site of irradiation }\end{array}$ & $\begin{array}{l}\text { All-grade immune-related AEs: } 20 \% \\
\text { dermatitis, } 8 \% \text { colitis, } 5 \% \text { transaminitis; } \\
\text { grade } \geq 3 \text { immune-related AEs: } 4 \% \\
\text { colitis, } 2 \% \text { transaminitis, } 2 \% \\
\text { hypophysitis }\end{array}$ & {$[127]$} \\
\hline RS & 137 & $\begin{array}{l}\text { Metastatic NSCLC, melanoma, and } \\
\text { RCC treated with WBRT (12-39 Gy), } \\
\text { SRS (15-30 Gy), or extracranial RT } \\
\text { (8-66 Gy) within a median } 85 \text { days } \\
\text { (IQR 34-181) of anti-PD-1 therapy }\end{array}$ & $\begin{array}{l}\text { Median OS } 249 \text { days (IQR 90-689) } \\
\text { following PD-1 blockade; on } \\
\text { multivariate analysis HR for death } 3.1 \\
(95 \% \mathrm{Cl} 1.7-5.9) \text { for NSCLC and HR } \\
3.2(95 \% \mathrm{Cl} 1.2-7.9) \text { for RCC vs. } \\
\text { melanoma }(p=0.0008)\end{array}$ & No grade 4-5 immune-related AEs & {$[120]$} \\
\hline RS & 17 & $\begin{array}{l}\text { NSCLC BMs treated with SRS or FSRT } \\
\text { (18-25 Gy X } 1-5 \text { fractions) within } \pm 6 \\
\text { mo of nivolumab or durvalumab }\end{array}$ & $\begin{array}{l}\text { Distant brain control rate } 57 \% \\
\text { (RT during or before PD-1/PD-L1 } \\
\text { blockade) vs. 0\% (RT after, } p=0.05 \text { ); } \\
\text { median OS for SRS during/before } \\
\text { PD-1/PD-L1 blockade vs. SRS after } \\
\text { (HR 3.6, 95\% Cl 0.74-26.9, } p=0.11 \text { ) } \\
\text { on multivariate analysis }\end{array}$ & $\begin{array}{l}\text { No neurologic/ cutaneous AEs with } \\
\text { SRS and anti-PD-1/PD-L1 therapy } \\
\text { ( } 41 \% \text { received prophylactic } \\
\text { dexamethasone before SRS); } 1 \\
\text { patient each discontinued } \\
\text { PD-1/PD-L1 inhibitor due to colitis } \\
\text { and pneumonitis }\end{array}$ & {$[128]$} \\
\hline $\mathrm{RS}$ & 137 & $\begin{array}{l}\text { Melanoma BMs treated with SRS or } \\
\text { WBRT (median } 20 \text { Gy, range } 12-30 \text { ) } \\
\text { within } 1 \text { year of PD-1 or CTLA-4 } \\
\text { blockade }\end{array}$ & $\begin{array}{l}\text { Median OS } 16.9 \text { mo; for } \\
\text { radionecrosis: } 37 \text { patients (27\%); } \\
\text { no difference in risk between } \\
\text { ipilimumab and pembrolizumab } \\
(p=0.549 \text { ) or CTLA-4 and PD-1 } \\
(p=0.86 \text { ); } 1 \text {-year OS } 78.4 \% \text { vs. } 55.06 \% \\
\text { (without radionecrosis, } p=0.341 \text { ) }\end{array}$ & See outcomes & {$[129]$} \\
\hline $\mathrm{RS}$ & 98 & $\begin{array}{l}\text { Advanced NSCLC treated with } \\
\text { palliative RT any time point before } \\
\text { (median } 9.5 \text { mo, range } 1-106 \text { ) first } \\
\text { cycle of pembrolizumab } 2 \text { or } \\
10 \mathrm{mg} / \mathrm{kg} \text { every } 2-3 \text { weeks }\end{array}$ & $\begin{array}{l}\text { Any previous RT vs. no previous RT: } \\
\text { median PFS } 4.4 \text { mo }(95 \% \mathrm{Cl} 2.1-8.6) \\
\text { vs. } 2.1 \text { mo }(95 \% \mathrm{Cl} 1.6-2.3, \mathrm{HR} 0.56 \text {, } \\
95 \% \mathrm{Cl} 0.34-0.91, p=0.019) \text {; median } \\
\text { OS } 10.7 \mathrm{mo}(95 \% \mathrm{Cl} 6.5-18.9) \text { vs. } 5.3 \\
\text { mo }(95 \% \mathrm{Cl} 2.7-7.7, \mathrm{HR} 0.58,95 \% \mathrm{Cl} \\
0.36-0.94, p=0.026)\end{array}$ & $\begin{array}{l}\text { All-grade treatment-related pulmon- } \\
\text { ary toxicity in } 3 \text { patients }(13 \% \text {, with } \\
\text { RT) vs. } 1 \text { ( } 1 \% \text { without RT, } p=0.046) \text {; } \\
\text { grade } \geq 3 \text { treatment-related } \\
\text { pulmonary toxicity similar in both } \\
\text { arms ( } 1 \text { each, } p=0.44)\end{array}$ & {$[121]$} \\
\hline RS & 108 & $\begin{array}{l}\text { Melanoma BMs treated with SRS } \\
\text { and/or WBRT (dose NR) within } \\
\pm 6 \text { weeks of various systemic } \\
\text { therapies }\end{array}$ & $\begin{array}{l}\text { In combination with RT: median OS } \\
7.5 \text { mo with CTLA-4 (95\% Cl 4.4- } \\
\text { 15.6), } 20.4 \text { mo PD-1 ( } 95 \% \text { Cl 8.8-NA), } \\
\text { and } 17.8 \text { mo BRAF } \pm \text { MEK inhibitor } \\
\text { (95\% Cl 11.8-NA) }\end{array}$ & $\begin{array}{l}2 \text { radiation necrosis }(S R S+\text { anti-PD- } 1) \\
\text { treated with surgery, steroids, and } \\
\text { bevacizumab }\end{array}$ & [122] \\
\hline
\end{tabular}

$R S$ retrospective study, BMs brain metastases, SRS stereotactic radiosurgery, FSRT fractionated stereotactic RT, Gy Gray, OS overall survival, NSCLC non-small cell lung cancer, IQR interquartile range, CNS central nervous system, $R T$ radiotherapy, WBRT whole brain radiation therapy, ORR overall response rate, NR not reported, $C l$ confidence interval, $C R$ complete response, $P R$ partial response, $S D$ stable disease, $P D$ progressive disease, $A E s$ adverse events, $R C C$ renal cell carcinoma, Gl gastrointestinal, HR hazard ratio, PFS progression-free survival, NA not applicable

not receive $\mathrm{RT}$, respectively [121]. In spite of these interesting clinical results, no data are provided on the type, dose, schedule of radiotherapy or the tumor burden of patients receiving therapy making the results hard to interpret. Interestingly, one retrospective series of 108 patients with melanoma brain metastases treated with SRS and/or WBRT concurrently with various contemporary systemic therapies highlighted that RT in combination with anti-PD-1 therapy produced among the best OS in the cohort without clinically significant increases in neurotoxicity [122].

\section{Safety analyses}

Retrospective safety analyses in patients with advanced solid tumors receiving $\mathrm{RT}$ and $\mathrm{PD}-1 / \mathrm{PD}-\mathrm{L} 1$ and/or CTLA-4 blockade have generally not demonstrated increased risk of toxicity with the combination beyond those expected with each modality independently $[123,124]$. There were no significant differences in toxicity rates between choice of PD-1/PD-L1 and CTLA-4 inhibitor or concurrent and sequential treatment with RT [124]. However, another series of 29 metastatic NSCLC patients given thoracic RT and 
PD-1/PD-L1 and/or CTLA-4 inhibitors identified 1 case of possibly treatment-related grade 5 pneumonitis in a patient who received 20 Gy over 5 fractions of thoracic RT initiated 1 month after the last dose of anti-PD-1 therapy [125]. Interestingly, case reports have documented the existence of PD-1 inhibitor-induced radiation recall pneumonitis even after 2 years of RT [126].

A multicenter safety analysis demonstrated no significant differences in immune-related AEs regardless of site of irradiation, between those receiving RT during/after checkpoint inhibitors and before checkpoint inhibitors ( $p=0.053)$, and between those receiving RT within 14 days or outside 14 days of checkpoint blockade $(p=0.06)$ [127]. One retrospective series demonstrated that brain RT and PD-1/PD-L1 blockade was relatively well-tolerated in patients with NSCLC brain metastases as toxicity rates were consistent with those seen with checkpoint inhibitors alone [128]. Interestingly, the distant brain control (out-of-field) rate for RT during/before PD-1/PD-L1 blockade was $57 \%$ compared to $0 \%$ (RT after, $p=0.05$ ). Another retrospective series of 137 patients with melanoma brain metastases identified 37 patients (27\%) who developed radionecrosis following SRS or WBRT and anti-CTLA-4 or anti-PD-1 therapy with a median time of onset of 6 months (range 1.3-31.4 months), which is comparable to rates seen in other series though prospective studies are limited [129-132]. Notably, 1-year OS did not significantly differ between those that developed radionecrosis vs. those without (Table 2). However, risk of radionecrosis was significantly associated with concurrent use of chemotherapy within 6 months of SRS (HR 2.20, 95\% CI 1.22-3.97, $p=0.009$ ) and increased number of lesions treated (HR 1.09, 95\% CI 1.03$1.15, p=0.002)$. The lack of significant difference in OS between presence and absence of radionecrosis conflicts with the results of other studies though the number of patients treated with brain RT and PD-1 blockade were likely much smaller $[130,133]$.

\section{Prospective studies}

A combined preclinical and phase I study was among the first to provide preliminary results for the efficacy of combined RT and checkpoint blockade in the prospective setting [134]. In the phase I dose-finding cohort of 5 patients given local RT for mixed response or asymptomatic progression to atezolizumab, dual RT and anti-PD-L1 therapy was well-tolerated without any dose-limiting toxicities (DLTs) or severe immune-mediated AEs and all 5 patients experienced at least SD (Table 3).

In another phase I trial, 9 patients with advanced melanoma received RT during induction, between induction and maintenance, or during maintenance therapy with ipilimumab and/or nivolumab [135]. Combined RT and checkpoint inhibition resulted in SD or response by first assessment at all irradiated sites and the best ORR was 44\% (4 patients with partial responses (PRs)) by World Health Organization (WHO) criteria (Table 3). A phase I/II study investigated the safety and efficacy of concurrent local palliative RT and durvalumab (PD-L1 inhibitor) in 10 patients with unresectable or metastatic advanced solid tumors [136]. When RT (to 15 localized lesions) was given a median of 8.5 days (range 1-35) from the last dose of durvalumab, the combination was generally tolerated with no grade $\geq 3$ RT-related AEs (Table 3). The 1-year OS and progression-free survival (PFS) rates were $44 \%$ (95\% CI 12-77) and 30\% (95\% CI 2-58), respectively.

Preliminary results from a phase I dose-finding study of stereotactic body RT (SBRT; 8 Gy X 1 or 5 Gy X 5) and durvalumab or the CTLA-4 inhibitor tremelimumab (or combination of all 3) was administered as second-line therapy to 24 metastatic pancreatic adenocarcinoma patients. No DLTs have been observed so far [137]. The best response was SD in 5 patients (21\%) with rapid progression within 4 weeks in an additional 5 patients. A phase II trial involving locally advanced NSCLC patients recently reported preliminary results from part I of the study [138]. Out of 10 enrolled patients, 7 have received atezolizumab added to consolidation carboplatin and paclitaxel following weekly carboplatin/paclitaxel and RT and 2 patients have demonstrated PD after 6 and 8 doses of the PD-L1 inhibitor. Given the safety and tolerability of patients in part I, criteria were met for advancement to part II of the study where atezolizumab will be added to the chemoradiation portion followed by consolidation atezolizumab, carboplatin, and paclitaxel.

Recently, the PD-L1 inhibitor durvalumab was granted FDA approval based on superior PFS but similar safety compared to placebo following platinum-based chemoradiation in locally advanced, unresectable NSCLC in the phase III PACIFIC trial [139]. Patients who did not demonstrate PD after $\geq 2$ cycles of platinum-based chemotherapy concurrent with definitive RT were administered durvalumab or placebo within 1-42 days for up to 1 year (Table 3 ). Improved outcomes were observed in the experimental arm irrespective of PD-L1 status or histology.

\section{Discussion}

Elucidated mechanisms underlying the immune stimulatory properties of RT are growing in complexity (Fig. 1). The CD8+ T-cell remains a crucial component in the ability of RT to elicit an antitumor immune response within and beyond the radiation field [140]. In addition, evidence is mounting to support that RT specifically upregulates $\mathrm{MHC}$ tumor-associated antigen complexes, enhances tumor antigen cross-presentation in draining lymph nodes, and increases $\mathrm{T}$-cell infiltration into 
Table 3 Prospective clinical studies with available results on the antitumor activity of combined radiation therapy and PD-1/PD-L1 blockade

\begin{tabular}{|c|c|c|c|c|c|}
\hline Study & $n$ & Design & Outcomes & Toxicities & Ref. \\
\hline Phase I & $\begin{array}{l}4 \text { solid tumors, } 1 \\
\text { hematologic } \\
\text { malignancy }\end{array}$ & $\begin{array}{l}\text { Atezolizumab } 0.01-20 \mathrm{mg} / \mathrm{kg} \\
\text { every } 3 \text { weeks (dose-finding } \\
\text { cohort) + local fractionated RT } \\
\text { (dose NR) for mixed responses or } \\
\text { asymptomatic PD }\end{array}$ & $\begin{array}{l}\text { Stabilization of systemic } \\
\text { progression in all } 5 \text { patients } \\
\text { (PR at systemic site in } 1 \\
\text { patient) }\end{array}$ & $\begin{array}{l}\text { Transient grade 1-2 } \\
\text { inflammatory AEs (fevers, } \\
\text { flu-like symptoms) observed } \\
\text { but no DLTs or serious } \\
\text { immune-related AEs }\end{array}$ & [134] \\
\hline Phase I & $\begin{array}{l}9 \text { advanced } \\
\text { melanoma }\end{array}$ & $\begin{array}{l}\text { Nivolumab } 0.3-10 \mathrm{mg} / \mathrm{kg} \text { every } \\
3 \text { weeks } X 21 \text { weeks (induction) } \\
\text { then every } 12 \text { weeks } X 84 \text { weeks } \\
\text { (maintenance) } \pm \text { ipilimumab } 3 \text { or } \\
10 \mathrm{mg} / \mathrm{kg} \text { every } 3 \text { weeks } X \\
9 \text { weeks (induction) then every } \\
12 \text { weeks X } 84 \text { weeks } \\
\text { (maintenance) or combined } \\
\text { nivolumab } 1 \mathrm{mg} / \mathrm{kg} \text { and } \\
\text { ipilimumab } 3 \mathrm{mg} / \mathrm{kg} \text { every } \\
3 \text { weeks X } 12 \text { weeks then } \\
\text { nivolumab } 3 \mathrm{mg} / \mathrm{kg} \text { every } \\
2 \text { weeks up to } 96 \text { weeks + RT } \\
\text { (median } 30 \mathrm{~Gy} X 5 \text { fractions, } \\
\text { range } 21-37.5 \mathrm{~Gy} X 1-15 \\
\text { fractions) during induction or } \\
\text { maintenance }\end{array}$ & $\begin{array}{l}\text { ORR } 44 \% \text { ( } 4 \text { PRs) as best } \\
\text { response by WHO criteria; } \\
\text { median OS } 27 \text { mo; } 1 \text { - and } \\
\text { 2-year OS rates of } 89 \text { and } \\
78 \% \text {, respectively }\end{array}$ & $\begin{array}{l}5 \text { patients with non- } \\
\text { laboratory grade } \geq 3 \mathrm{AEs}, 2 \\
\text { RT-related grade } \geq 3 \mathrm{AEs} \\
\text { (intracranial hemorrhage, } \\
\text { diarrhea) }\end{array}$ & [135] \\
\hline Phase I/II & $\begin{array}{l}10 \text { unresectable or } \\
\text { metastatic solid } \\
\text { tumors ( } \geq 5 \% \text { PD-L1 } \\
\text { expression) }\end{array}$ & $\begin{array}{l}\text { Durvalumab } 10 \mathrm{mg} / \mathrm{kg} \text { every } \\
2 \text { weeks + local RT (median } 20 \mathrm{~Gy} \text {, } \\
\text { range } 6-33 \text { X median } 5 \text { fractions, } \\
\text { range } 1-10 \text { ) given a median of } \\
8.5 \text { days (range } 1-35 \text { ) of last dose } \\
\text { of durvalumab }\end{array}$ & $\begin{array}{l}\text { In-field ORR 60\% (2/10 CRs, } \\
4 / 10 \text { PRs); median OS } 11.5 \\
\text { mo ( } 95 \% \text { Cl 8.8-13.7); median } \\
\text { PSF } 6.2 \text { months ( } 95 \% \text { Cl } \\
4.5-12.4) ; \text { out-of-field 10/14 } \\
\text { SD, no responses or abscopal } \\
\text { effects were seen }\end{array}$ & $\begin{array}{l}5 \text { cases of ( } 50 \%) \text { RT-related } \\
\text { grade } 2 \text { AEs ( } 3 \text { mucositis, } \\
1 \text { diarrhea, } 1 \text { vomiting) }\end{array}$ & [136] \\
\hline Phase I & $\begin{array}{l}24 \text { metastatic } \\
\text { pancreatic } \\
\text { adenocarcinoma }\end{array}$ & $\begin{array}{l}\text { SBRT ( } 8 \text { Gy } X 1 \text { fraction or } 25 \text { Gy } \\
\times 25 \text { fractions) + durvalumab } \\
\text { (dose NR) every } 2 \text { weeks or } \\
\text { tremelimumab (dose NR) every } \\
4 \text { weeks } \times 6 \text { doses then every } \\
12 \text { weeks for } 3 \text { doses or triple } \\
\text { therapy }\end{array}$ & $\begin{array}{l}\text { SD as best ORR in } 5 \text { patients } \\
(21 \%)\end{array}$ & $\begin{array}{l}\text { No DLTs observed; most } \\
\text { common AE was grade } 1-2 \\
\text { fatigue at dose level } 2\end{array}$ & [137] \\
\hline Phase II & $\begin{array}{l}10 \text { locally advanced } \\
\text { NSCLC }\end{array}$ & $\begin{array}{l}\text { Weekly carboplatin (AUC 2) and } \\
\text { weekly paclitaxel } 50 \mathrm{mg} / \mathrm{m}^{2}+\text { RT } \\
5 \text { days/week for } 6-7 \text { weeks } \\
\text { (60-66 Gy over } 30-33 \text { fractions) } \\
\text { followed by atezolizumab } \\
1200 \mathrm{mg} \text { every } 3 \text { weeks }+ \\
\text { consolidation carboplatin (AUC 6) } \\
\text { and paclitaxel } 200 \mathrm{mg} / \mathrm{m}^{2} \text { on } \\
\text { days } 1 \text { and } 22 \text { for } 2 \text { cycles then } \\
\text { atezolizumab alone up to } 1 \text { year }\end{array}$ & $\begin{array}{l}\text { Out of } 7 \text { patients receiving } \\
\text { atezolizumab, } 2 \text { patients } \\
\text { developed PD after } 6 \text { and } 8 \\
\text { doses of atezolizumab }\end{array}$ & $\begin{array}{l}3 \text { patients with potential } \\
\text { immune-related AEs ( } 1 \text { grade } \\
3 \text { arthralgia, } 1 \text { grade } 2 \\
\text { pneumonitis resolved with } \\
\text { steroids, } 1 \text { grade } 3 \text { dyspnea) }\end{array}$ & [138] \\
\hline Phase III & $\begin{array}{l}709 \text { stage III, locally } \\
\text { advanced, } \\
\text { unresectable NSCLC }\end{array}$ & $\begin{array}{l}2 \text { or more cycles of platinum- } \\
\text { based chemotherapy (defined by } \\
\text { local practice) + concurrent } \\
\text { definitive RT ( } 54-66 \text { Gy with } \\
\text { mean dose to the lung < } 20 \text { Gy } \\
\text { or volume of lung parenchyma } \\
\text { receiving } \geq 20 \text { Gy }<35 \% \text { ) } \\
\text { followed by (within } 1-42 \text { days) } \\
\text { durvalumab } 10 \mathrm{mg} / \mathrm{kg} \text { every } \\
2 \text { weeks up to } 1 \text { year or placebo } \\
\text { if no PD during chemoradiation }\end{array}$ & $\begin{array}{l}\text { Median PFS } 16.8 \text { months } \\
\text { ( } 95 \% \mathrm{Cl} 13.0-18.1) \text { vs. } \\
5.6 \text { months }(95 \% \mathrm{Cl} 4.6-7.8) \\
\text { with placebo (HR 0.52, 95\% Cl } \\
0.42-0.65, p<0.001) \text {; median } \\
\text { TTD or distant metastasis } \\
23.2 \text { months }(95 \% \mathrm{Cl} 23.2-\mathrm{NE}) \\
\text { vs. } 14.6 \text { months ( } 95 \% \mathrm{Cl} \\
10.6-18.6 \text { ) with placebo } \\
\text { (HR 0.52, 95\% Cl } 0.39-0.69 \text {, } \\
p<0.001) \text {; ORR } 28.4 \% \text { vs. } \\
16.0 \% \text { with placebo }(p<0.001)\end{array}$ & $\begin{array}{l}\text { Grade } 3-4 \text { AEs } 29.9 \% \text { vs. } \\
26.1 \% \text { (placebo); most } \\
\text { common grade } 3-4 \text { AEs } \\
\text { pneumonia ( } 4.4 \% \text { vs. } 3.8 \%) \text {, } \\
\text { pneumonitis ( } 3.4 \% \text { vs. } 2.6 \%) \text {, } \\
\text { and anemia ( } 2.9 \% \text { vs. } 3.4 \% \text { in } \\
\text { durvalumab vs. placebo arms }\end{array}$ & [139] \\
\hline
\end{tabular}

$R T$ radiation therapy, NR not reported, $P D$ progressive disease, $P R$ partial response, $D L T$ dose-limiting toxicity, $A E s$ adverse events, Gy Gray, ORR overall response rate, $P R$ partial response, WHO World Health Organization, $C$ confidence interval, $S D$ stable disease, SBRT stereotactic body radiation therapy, NSCLC non-small cell lung cancer, $A U C$ area under curve, $C R$ complete response, PFS progression-free survival, $H R$ hazard ratio, $T D$ time to death, NE not estimable or reached 
tumors [79, 141]. Local RT appears necessary in eliciting abscopal effects, but RT alone remains insufficient in complete eradication of local and distant tumors likely, in part, due to activation of negative T-cell regulatory pathways including the PD-1/PD-L1 axis and immune checkpoints such as CTLA-4 [76, 86, 87]. However, RT has been shown to upregulate expression of PD-1 and PD-L1 on immune and tumor cells rendering it an attractive modality to combine with PD-1/PD-L1 blockade [71, 76, 78, 79, 86, 97]. Activation of cGAS-STING signaling has also been recognized to mediate systemic tumor rejection by combined RT and checkpoint blockade given that knockdown of cGAS and STING in cancer cells abrogated priming of CD8+ T-cells in tumor-draining sites and infiltration of abscopal tumors by CD8+ T-cells [89].

In efforts to characterize the synergistic antitumor activity of combined RT and PD-1/PD-L1 blockade, numerous studies have identified significant elevations in $\mathrm{CD} 8+\mathrm{IFN} \gamma+\mathrm{TNF} \alpha+\mathrm{T}$-cells but decreases in CD4+ FOXP3+ Tregs leading to an increased CD8+/Treg ratio, increases in tumor-antigen specific CD8+ TILs with a CD44+ effector memory phenotype, decreases in immunosuppressive MDSCs, reinvigoration of CD8+ TILs with an exhausted phenotype, and increases in TCR repertoire clonality and diversity of the TCR repertoire in irradiated and out-of-field sites as a consequence of combination radioimmunotherapy [61, 72, 76, 79, 88]. Furthermore, addition of anti-PD-L1 therapy to tumors that are nonresponsive to RT has shown the ability to reverse RT-induced tumor equilibrium in favor of tumor regression [92]. Resistance to $\mathrm{RT}$ also appears to be regulated by host STING activation via CCR2; additional targeting of the CCR2 pathway may therefore aid in reversing RT resistance in the context of checkpoint blockade [93]. Conversely, integration of RT to anti-PD-1-resistant tumors restores response to PD-1 blockade highlighted by RT-induced IFN- $\gamma$ production and MHC class I expression [91].

Immune modulation from immune checkpoint inhibitors and RT through nonredundant pathways that altogether contribute to synergistic antitumor activity now represents an emerging theme from ongoing investigations in combination RT and immunotherapy $[61,77,85,88,90,142]$. For example, anti-CTLA-4 therapy has been shown to predominantly inhibit Tregs, increase the CD8+ T-cell/Treg ratio, and promote T-cell expansion. Radiation enhances the diversity of the TCR repertoire, shapes the TCR repertoire of expanded peripheral $\mathrm{T}$-cell clones in an antigen-driven selection manner, and promotes tumor infiltration by antigen-specific CD8+ T-cells. Addition of PD-1/PD-L1 blockade reverses T-cell exhaustion to offset decreases in the CD8+ T-cell/Treg ratio and further enhances oligoclonal T-cell proliferation.
Several points of consideration remain that could potentially impact the rational combination of RT and PD-1/PD-L1 inhibitors and their efficacy. Firstly, immunogenic cell death has been shown to be induced by RT in a dose-dependent manner in vitro [68]. In other preclinical studies, increasing radiation doses (single fractions above 7.5 Gy but not 5 Gy) were immunostimulatory, associated with elevated IFN $-\gamma$ production, and prevented increases in Tregs [143]. At higher doses (single fractions $\geq 15 \mathrm{~Gy}$ ), dose-dependent increases in Tregs were observed and associated with no improvement in antitumor immune responses. Fractionation of the 15 Gy generally resulted in superior immune responses compared to single-fraction $15 \mathrm{~Gy}$. In a seminal study of 2 preclinical mouse carcinoma models, evaluation of RT (20 Gy X 1, 8 Gy X 3, or 6 Gy X 5 fractions over consecutive days) in combination with an anti-CTLA-4 antibody determined that fractionated RT but not single-dose RT achieved significantly enhanced tumor responses both within and outside the radiation field (abscopal effects) when combined with CTLA-4 blockade [55]. It has been further corroborated that fractionated RT (8 Gy X 3) with checkpoint blockade was able to elicit abscopal effects whereas checkpoint blockade with RT doses $\geq 20$ Gy single dose were characterized by complete loss of abscopal responses through induction of Trex1 and downregulation of type I IFN signaling [89].

The timing of RT in relation to administration of checkpoint inhibitors represents another issue of discussion. Preclinical data support that RT-associated increases in the CD8+ T-cell/Treg ratio, CD8+ T-cell PD-1 expression, and tumor cell PD-L1 expression often occur early with peak levels occurring within 24-96 h post-RT $[81,86]$. In an elegant study exploring combined anti-PD-L1 therapy and fractionated RT (10 Gy in 5 daily fractions), the addition of PD-L1 blockade on day 1 of RT (concurrent regimen starting at the beginning of RT), day 5 of RT (concurrent regimen starting at the end of RT), or 7 days after RT (sequential therapy) showed that there was no significant difference in OS between either concurrent therapy schedules [86]. However, sequential therapy was ineffective in enhancing OS compared to RT alone (median OS 30 days vs. 35 days, $p>0.05$ ). Interestingly, the rise in PD-1 expression on CD8+ T-cells was evident up to 7 days after the last dose of RT, after which PD-1 levels significantly decreased compared to time-matched controls. In the clinical setting, retrospective series have documented a wider range of schedules in combining radioimmunotherapy ranging from $\mathrm{RT}$ at any point prior to immune checkpoint therapy, within 1 month of administration of checkpoint inhibitors, or up to 1 year of checkpoint blockade [117, 121, 124, 129]. Moreover, results have been largely mixed on the impact of scheduling of 
RT and checkpoint blockade on survival as several retrospective studies have identified that there is no significant difference in OS between concurrent and nonconcurrrent radioimmunotherapy while another study demonstrated a significant improvement in PFS and OS in patients having ever received RT prior to PD-1 blockade compared to those with no prior RT $[116,117,121]$. It is worthwhile to mention that these retrospective studies were likely limited by variability in RT modality, tumor histology, patient characteristics, and cohort size. Notably, abscopal effects have been observed in $56 \%$ of patients with the addition of late RT to PD-1 blockade as well ( $>3$ months of insufficient response to anti-PD-1 monotherapy) [119].

Another point of consideration in clinical trial design is the issue of toxicity with combined RT and PD-1/PD-L1 blockade. Several preclinical studies demonstrated more findings of abnormal alveoli, inflammatory changes, exudates in the alveolar septa, and cardiac toxicity in mice receiving thoracic RT and anti-PD-1 therapy, when compared to controls, though effects on survival have been mixed [100-102]. Retrospective analyses have generally shown no increased risk of toxicity with the combination of RT and checkpoint blockade beyond those expected with either modality alone [121, 124, 127]. For brain RT, a study of 137 patients treated with SRS or WBRT in combination with PD-1 or CTLA-4 blockade identified radionecrosis in $27 \%$ though 1 -year OS did not significantly differ between those that developed radionecrosis and those that did not [129]. Reassuringly, retrospective series of $>200$ patients receiving combined RT and immunotherapy have demonstrated that there are no significant differences in toxicities regardless of site of irradiation, choice of checkpoint inhibitor, or treatment schedule (concurrent vs. sequential) [124, 127].

Taking together the preclinical evidence on the kinetics of PD-1 and PD-L1 expression in relation to RT and the clinical data on the safety and tolerability of radioimmunotherapy, there is growing evidence to support that PD-1/PD-L1 blockade is optimal when synchronized with the administration of fractionated RT to prevent the development of immunological anergy [144]. Indeed, the concept of administering PD-1/PD-L1 inhibitors concurrently or immediately following fractionated RT has already been employed in clinical trials with evidence that the combination is generally well-tolerated (Table 3). However, despite our increased understanding, preclinical and clinical data have yet to offer a consensus on optimal dosing and modality sequencing to date [68]. The majority of retrospective and prospective studies on combination RT and checkpoint blockade have predominantly used fractionated dosing schemes (Tables 2 and 3). However, depending on the tumor type, target site, and modality employed, total RT doses from retrospective series have ranged widely from 8 to 74 Gy (Table 2). Of the limited number of larger prospective trials, PD-1 and PD-L1 blockade have often been incorporated into standard dosing regimens of SBRT and chemoradiation routinely used in the treatment of locally advanced pancreatic cancer and NSCLC, for example (Table 3).

It is worthwhile to mention that the Phase III PACIFIC trial demonstrated the superiority of chemoradiation followed by durvalumab when the latter was included within 1-42 days of chemoradiation over chemoradiation followed by placebo in locally advanced NSCLC [139]. On review of the study protocol and Supplementary Appendix, the investigators emphasized the initiation of durvalumab as close as possible to chemoradiation when antigen release and PD-L1 expression is likely to be at its greatest. An analysis of benefit in those receiving durvalumab closer to chemoradiation compared to those treated later relative to chemoradiation was not provided; an analysis of this nature may provide further insight on the proposed synergism offered by this combination. For reasons which are unclear, the median PFS of the placebo arm (5.6 months) appears worse than historical standards [145]. It is also unclear whether the benefit derived from the combination arm is due to the efficacy of immunotherapy in settings of smaller disease volume as seen previously [146]. All of these are potential factors that may contribute to the difference seen in efficacy between experimental and control arms.

Despite the promising results and feasibility of the PACIFIC trial, clinical studies on an upper threshold RT dose with checkpoint inhibition by which no further improvement in antitumor immunity is offered (as foreshadowed by preclinical evidence discussed previously) are virtually nonexistent, yet duly warranted. Dedicated dose-escalation studies on combination PD-1/PD-L1 inhibitors and RT are also needed in other tumor types to determine safety and tolerability. Early phase studies of this nature are emerging and have demonstrated the feasibility of this combination while recognizing the importance of timing of checkpoint blockade with respect to RT administration [147]. Extrapolation of RT dose effects from animal to human studies is not straightforward and great caution is needed in applying dosing schemes and regimens involving combination RT and PD-1/PD-L1 blockade in human patients [148]. Further understanding of the mechanistic and dynamic immunostimulatory properties of RT and PD-1/PD-L1 blockade are undoubtedly warranted with validation in (ideally) prospective cohorts prior to maximizing tumor responses with the combination. The ability to optimize immune responses in the future with radioimmunotherapy may potentially depend on the immunotherapeutic strategy used, tumor histology, balance between proimmunogenic and immunosuppressive effects of either modality, and other host factors [50, 148]. 
Lastly, phase I trials of RT and anti-PD-1 therapy have already provided glimpses into potential mechanisms of failure even with the combination as 1 patient with metastatic RCC who rapidly progressed on combined RT and pembrolizumab had biomarker analyses showing an absence of TILs and presence of other nonredundant immune checkpoints in the tumor microenvironment and periphery that may have contributed to treatment failure [149]. Accordingly, future studies may seek to target multiple checkpoints in combination with RT. The incorporation of additional immunotherapeutic strategies or other systemic therapies to enhance immune responses with RT represents another potential avenue of therapy. Several studies have investigated combined RT, PD-1/PD-L1, and CTLA-4 blockade while others have evaluated RT and immune checkpoint therapy with various combinations of chemotherapy, vaccine therapies, or targeted therapies across a spectrum of cancers [150-157].

\section{Abbreviations \\ AEs: Adverse events; CCR2: Chemokine receptor type 2; CGAS: Cyclic GMP- AMP (cGAMP) synthase; Cl: Confidence interval; CR: Complete response; CTLA-4: Cytotoxic T-lymphocyte antigen 4; DLTs: Dose-limiting toxicities; FDA: Food and drug administration; GEMM: Genetically engineered mouse model; Gy: Gray; HCC: Hepatocellular carcinoma; HR: Hazard ratio; HSCT: Hematopoietic stem cell transplantation; IFNY: Interferon- $\gamma$; IQR: Interquartile range; LAG3: Lymphocyte activation gene 3 protein; MDSCs: Myeloid-derived suppressor cells; MHC: Major histocompatibility complex; NSCLC: Non-small cell lung cancer; OS: Overall survival; PD- 1: Programmed cell death 1; PD-L1: Programmed death-ligand 1; PFS: Progression-free survival; PR: Partial response; RCC: Renal cell carcinoma; RFA: Radiofrequency ablation; RT: Radiation therapy; SABR: Stereotactic ablative radiotherapy; SD: Stable disease; SRS: Stereotactic radiosurgery; STING: Stimulator of interferon genes; TAMs: Tumor-associated macrophages; TBI: Total body irradiation; TCR: T-cell receptor; TILs: Tumor-infiltrating lymphocytes; TIM-3: T-cell immunoglobulin mucin-3; TNFa: Tumor necrosis factor-a; Tregs: Regulatory T-cells; WBRT: Whole brain radiotherapy; WHO: World Health Organization; WT: Wild-type}

\section{Authors' contributions}

$J G, T L, E M, A H$ and RT - literature search and review, writing, and editing; JG and RT - conception and design and editing. All authors read and approved the final manuscript.

\section{Ethics approval and consent to participate}

Not applicable

\section{Competing interests}

The authors declare that they have no competing interests.

\section{Publisher's Note}

Springer Nature remains neutral with regard to jurisdictional claims in published maps and institutional affiliations.

\footnotetext{
Author details

'Department of Medical Oncology, City of Hope National Medical Center, Duarte, CA, USA. ${ }^{2}$ Division of Angiography and Interventional Radiology, Brigham and Women's Hospital, Harvard Medical School, Boston, MA, USA. ${ }^{3}$ Division of Medical Oncology, Department of Medicine, Samuel Oschin Comprehensive Cancer Institute, Cedars-Sinai Medical Center, Los Angeles, CA, USA. ${ }^{4}$ Departments of Radiation Oncology and Biomedical Sciences, Samuel Oschin Comprehensive Cancer Institute, Cedars-Sinai Medical Center, 8700 Beverly Blvd, AC 1023, Los Angeles, CA 90048, USA.
}

Received: 26 December 2017 Accepted: 16 May 2018

Published online: 04 June 2018

\section{References}

1. Dong H, Strome SE, Salomao DR, Tamura H, Hirano F, Flies DB, et al. Tumorassociated B7-H1 promotes T-cell apoptosis: a potential mechanism of immune evasion. Nat Med. 2002;8:793-800.

2. Iwai $Y$, Ishida M, Tanaka Y, Okazaki T, Honjo T, Minato N. Involvement of PD-L1 on tumor cells in the escape from host immune system and tumor immunotherapy by PD-L1 blockade. Proc Natl Acad Sci U S A. 2002:99:12293-7.

3. Hamid O, Robert C, Daud A, Hodi FS, Hwu WJ, Kefford R, et al. Safety and tumor responses with lambrolizumab (anti-PD-1) in melanoma. N Engl J Med. 2013;369:134-44.

4. Larkin J, Chiarion-Sileni V, Gonzalez R, Grob JJ, Cowey CL, Lao CD, et al. Combined nivolumab and ipilimumab or monotherapy in untreated melanoma. N Engl J Med. 2015;373:23-34.

5. Postow MA, Chesney J, Pavlick AC, Robert C, Grossmann K, McDermott D, et al. Nivolumab and ipilimumab versus ipilimumab in untreated melanoma. N Engl J Med. 2015;372:2006-17.

6. Ribas A, Puzanov I, Dummer R, Schadendorf D, Hamid O, Robert C, et al. Pembrolizumab versus investigator-choice chemotherapy for ipilimumabrefractory melanoma (KEYNOTE-002): a randomised, controlled. phase 2 trial Lancet Oncol. 2015;16:908-18.

7. Ribas A, Wolchok JD, Robert C, Kefford R, Hamid O, Daud A, et al. P0116 Updated clinical efficacy of the anti-PD-1 monoclonal antibody pembrolizumab (MK-3475) in 411 patients with melanoma [abstract] Eur J Cancer. 2015; 51:Abstr nr P0116.

8. Robert C, Ribas A, Wolchok JD, Hodi FS, Hamid O, Kefford R, et al. Antiprogrammed-death-receptor-1 treatment with pembrolizumab in ipilimumab-refractory advanced melanoma: a randomised dose-comparison cohort of a phase 1 trial. Lancet. 2014:384:1109-17.

9. Robert C, Schachter J, Long GV, Arance A, Grob JJ, Mortier L, et al. Pembrolizumab versus ipilimumab in advanced melanoma. N Engl J Med. 2015:372:2521-32.

10. Weber JS, D'Angelo SP, Minor D, Hodi FS, Gutzmer R, Neyns B, et al. Nivolumab versus chemotherapy in patients with advanced melanoma who progressed after anti-CTLA-4 treatment (CheckMate 037): a randomised, controlled, open-label, phase 3 trial. Lancet Oncol. 2015;16:375-84.

11. Borghaei H, Paz-Ares L, Horn L, Spigel DR, Steins M, Ready NE, et al. Nivolumab versus docetaxel in advanced nonsquamous non-small-cell lung cancer. N Engl J Med. 2015;373:1627-39.

12. Brahmer J, Reckamp KL, Baas P, Crinò L, Eberhardt WE, Poddubskaya E, et al. Nivolumab versus docetaxel in advanced squamous-cell non-small-cell lung cancer. N Engl J Med. 2015;373:123-35.

13. Garon EB, Rizvi NA, Hui R, Leighl N, Balmanoukian AS, Eder JP, et al. Pembrolizumab for the treatment of non-small-cell lung cancer. N Engl J Med. 2015;372:2018-28.

14. Herbst RS, Baas P, Kim DW, Felip E, Pérez-Gracia JL, Han JY, et al. Pembrolizumab versus docetaxel for previously treated, PD-L1-positive, advanced non-small-cell lung cancer (KEYNOTE-010): a randomised controlled trial. Lancet. 2016:387:1540-50.

15. Langer CJ, Gadgeel SM, Borghaei H, Papadimitrakopoulou VA, Patnaik A Powell SF, et al. Carboplatin and pemetrexed with or without pembrolizumab for advanced, non-squamous non-small-cell lung cancer: a randomised, phase 2 cohort of the open-label KEYNOTE-021 study. Lancet Oncol. 2016;17:1497-508

16. Reck M, Rodríguez-Abreu D, Robinson AG, Hui R, Csőszi T, Fülöp A, et al. Pembrolizumab versus chemotherapy for PD-L1-positive non-small-cell lung cancer. N Engl J Med. 2016:375:1823-33.

17. Ferris RL, Blumenschein G, Fayette J, Guigay J, Colevas AD, Licitra L, et al. Nivolumab for recurrent squamous-cell carcinoma of the head and neck. N Engl J Med. 2016:375:1856-67.

18. Motzer RJ, Escudier B, McDermott DF, George S, Hammers HJ, Srinivas S, et al. Nivolumab versus everolimus in advanced renal-cell carcinoma. N Engl J Med. 2015;373:1803-13.

19. Seiwert TY, Burtness B, Mehra R, Weiss J, Berger R, Eder JP, et al. Safety and clinical activity of pembrolizumab for treatment of recurrent or metastatic squamous cell carcinoma of the head and neck (KEYNOTE-012): an openlabel, multicentre, phase 1b trial. Lancet Oncol. 2016;17:956-65. 
20. Sharma P, Retz M, Siefker-Radtke A, Baron A, Necchi A, Bedke J, et al. Nivolumab in metastatic urothelial carcinoma after platinum therapy (CheckMate 275): a multicentre, single-arm, phase 2 trial. Lancet Oncol. 2017:18:312-22

21. Balar AV, Castellano DE, O'Donnell PH, Grivas P, Vuky J, Powles T, et al. Pembrolizumab as first-line therapy in cisplatin-ineligible advanced urothelial cancer: results from the total KEYNOTE-052 study population [abstract]. J Clin Oncol. 2017:35:Abstr nr 284

22. Bellmunt J, de Wit R, Vaughn DJ, Fradet $Y$, Lee $J$, Fong $L$, et al. Pembrolizumab as second-line therapy for advanced urothelial carcinoma. N Engl J Med. 2017;376:1015-26.

23. Ansell SM, Lesokhin AM, Borrello I, Halwani A, Scott EC, Gutierrez M, et al. PD-1 blockade with nivolumab in relapsed or refractory Hodgkin's lymphoma. N Engl J Med. 2015;372:311-9.

24. Chen $R$, Zinzani PL, Fanale MA, Armand $P$, Johnson NA, Brice $P$, et al. Phase II study of the efficacy and safety of pembrolizumab for relapsed/refractory classic hodgkin lymphoma. J Clin Oncol. 2017;35:2125-32.

25. Younes A, Santoro A, Shipp M, Zinzani PL, Timmerman JM, Ansell S, et al. Nivolumab for classical Hodgkin's lymphoma after failure of both autologous stem-cell transplantation and brentuximab vedotin: a multicentre, multicohort, single-arm phase 2 trial. Lancet Oncol. 2016;17:1283-94.

26. Apolo AB, Ellerton JA, Infante JR, Agrawal M, Gordon MS, Aljumaily R, et al. Updated efficacy and safety of avelumab in metastatic urothelial carcinoma (mUC): pooled analysis from 2 cohorts of the phase $1 \mathrm{~b}$ javelin solid tumor study [abstract]. J Clin Oncol. 2017;35:Abstr nr 4528.

27. Apolo AB, Infante JR, Balmanoukian A, Patel MR, Wang D, Kelly K, et al. Avelumab, an anti-programmed death-ligand 1 antibody, in patients with refractory metastatic urothelial carcinoma: results from a multicenter, phase Ib study. J Clin Oncol. 2017;35:2117-24.

28. Balar AV, Galsky MD, Rosenberg JE, Powles T, Petrylak DP, Bellmunt J, et al. Atezolizumab as first-line treatment in cisplatin-ineligible patients with locally advanced and metastatic urothelial carcinoma: a single-arm, multicentre. phase 2 trial Lancet. 2017;389:67-76.

29. Diaz LA, Marabelle A, Delord JP, Shapira-Frommer R, Geva R, Peled N, et al. Pembrolizumab therapy for microsatellite instability high (MSI-H) colorectal cancer (CRC) and non-CRC [abstract]. J Clin Oncol. 2017;35:Abstr nr 3071

30. Diaz LA, Uram JN, Wang H, Bartlett B, Kemberling $H$, Eyring A, et al. Programmed death-1 blockade in mismatch repair deficient cancer independent of tumor histology [abstract]. J Clin Oncol. 2016:34:Abstr nr 3003.

31. Fader AN, Diaz LA, Armstrong DK, Tanner EJ, Uram J, Eyring A, et al. Preliminary results of a phase $\|$ study: PD-1 blockade in mismatch repair-deficient, recurrent or persistent endometrial cancer. Gynecol Oncol. 2016;141:206-7.

32. Fehrenbacher $L$, Spira A, Ballinger $M$, Kowanetz $M$, Vansteenkiste J, Mazieres $J$, et al. Atezolizumab versus docetaxel for patients with previously treated non-small-cell lung cancer (POPLAR): a multicentre, open-label, phase 2 randomised controlled trial. Lancet. 2016;387:1837-46.

33. Hahn NM, Powles T, Massard C, Arkenau HT, Friedlander TW, Hoimes CJ, et al. Updated efficacy and tolerability of durvalumab in locally advanced or metastatic urothelial carcinoma (UC) [abstract]. J Clin Oncol. 2017;35:Abstr nr 4525.

34. Kaufman HL, Russell J, Hamid O, Bhatia S, Terheyden P, D'Angelo SP, et al. Avelumab in patients with chemotherapy-refractory metastatic Merkel cell carcinoma: a multicentre, single-group, open-label, phase 2 trial. Lancet Oncol. 2016;17:1374-85.

35. Le DT UJN, Wang H, Bartlett B, Kemberling $H$, Eyring A, et al. Programmed death-1 blockade in mismatch repair deficient colorectal cancer [abstract]. J Clin Oncol. 2016;34:Abstr nr 103.

36. Le DT, Uram JN, Wang H, Bartlett BR, Kemberling H, Eyring AD, et al. PD-1 blockade in tumors with mismatch-repair deficiency. N Engl J Med. 2015;372:2509-20.

37. Le DT UJN, Wang H, Kemberling H, Eyring A, Bartlett B, et al. PD-1 blockade in mismatch repair deficient non-colorectal gastrointestinal cancers [abstract]. J Clin Oncol. 2016;34:Abstr nr 195.

38. Massard C, Gordon MS, Sharma S, Rafii S, Wainberg ZA, Luke J, et al. Safety and efficacy of durvalumab (MEDI4736), an anti-programmed cell death ligand-1 immune checkpoint inhibitor, in patients with advanced urothelial bladder cancer. J Clin Oncol. 2016;34:3119-25.
39. Overman MJ, McDermott R, Leach JL, Lonardi S, Lenz HJ, Morse MA, et al. Nivolumab in patients with metastatic DNA mismatch repair-deficient or microsatellite instability-high colorectal cancer (CheckMate 142): an openlabel, multicentre, phase 2 study Lancet Oncol 2017: https://doi.org/10. 1016/S1470-2045(1017)30422-30429.

40. Rittmeyer A, Barlesi F, Waterkamp D, Park K, Ciardiello F, von Pawel J, et al. Atezolizumab versus docetaxel in patients with previously treated nonsmall-cell lung cancer (OAK): a phase 3, open-label, multicentre randomised controlled trial. Lancet. 2017;389:255-65.

41. Rosenberg JE, Hoffman-Censits J, Powles T, van der Heijden MS, Balar AV, Necchi A, et al. Atezolizumab in patients with locally advanced and metastatic urothelial carcinoma who have progressed following treatment with platinum-based chemotherapy: a single-arm, multicentre, phase 2 trial. Lancet. 2016;387:1909-20.

42. El-Khoueiry AB, Sangro B, Yau T, Crocenzi TS, Kudo M, Hsu C, et al. Nivolumab in patients with advanced hepatocellular carcinoma (CheckMate 040): an open-label, non-comparative, phase 1/2 dose escalation and expansion trial. Lancet. 2017;389:2492-502.

43. Fuchs CS, Doi T, Jang RW, Muro K, Satoh T, Machado M, et al. KEYNOTE-059 cohort 1: efficacy and safety of pembrolizumab (pembro) monotherapy in patients with previously treated advanced gastric cancer [abstract]. J Clin Oncol. 2017;35:Abstr nr 4003.

44. Mole RH. Whole body irradiation; radiobiology or medicine? $\mathrm{Br} J$ Radiol. 1953:26:234-41.

45. Demaria S, Ng B, Devitt ML, Babb JS, Kawashima N, Liebes L, et al. lonizing radiation inhibition of distant untreated tumors (abscopal effect) is immune mediated. Int J Radiat Oncol Biol Phys. 2004;58:862-70.

46. Ma Y, Kepp O, Ghiringhelli F, Apetoh L, Aymeric L, Locher C, et al. Chemotherapy and radiotherapy: cryptic anticancer vaccines. Semin Immunol. 2010;22:113-24.

47. Nobler MP. The abscopal effect in malignant lymphoma and its relationship to lymphocyte circulation. Radiology. 1969:93:410-2.

48. Stone HB, Peters $\amalg$, Milas L. Effect of host immune capability on radiocurability and subsequent transplantability of a murine fibrosarcoma. J Natl Cancer Inst. 1979;63:1229-35.

49. Formenti SC, Demaria S. Systemic effects of local radiotherapy. Lancet Oncol. 2009;10:718-26.

50. Formenti SC, Demaria S. Combining radiotherapy and cancer immunotherapy: a paradigm shift. J Natl Cancer Inst. 2013;105:256-65.

51. Frey $B$, Rubner $Y$, Wunderlich $R$, Weiss EM, Pockley $A G$, Fietkau $R$, et al, Induction of abscopal anti-tumor immunity and immunogenic tumor cell death by ionizing irradiation - implications for cancer therapies. Curr Med Chem. 2012;19:1751-64

52. Sharabi $A B$, Lim M, DeWeese $T L$, Drake CG. Radiation and checkpoint blockade immunotherapy: radiosensitisation and potential mechanisms of synergy. Lancet Oncol. 2015;16:e498-509.

53. Tang C, Wang $X$, Soh $H$, Seyedin S, Cortez MA, Krishnan S, et al. Combining radiation and immunotherapy: a new systemic therapy for solid tumors? Cancer Immunol Res. 2014:2:831-8.

54. Demaria S, Kawashima N, Yang AM, Devitt ML, Babb JS, Allison JP, et al. Immune-mediated inhibition of metastases after treatment with local radiation and CTLA-4 blockade in a mouse model of breast cancer. Clin Cancer Res. 2005:11:728-34.

55. Dewan MZ, Galloway AE, Kawashima N, Dewyngaert JK, Babb JS, Forment SC, et al. Fractionated but not single-dose radiotherapy induces an immune-mediated abscopal effect when combined with anti-CTLA-4 antibody. Clin Cancer Res. 2009;15:5379-88.

56. Belcaid Z, Phallen JA, Zeng J, See AP, Mathios D, Gottschalk C, et al. Focal radiation therapy combined with 4-1BB activation and CTLA-4 blockade yields long-term survival and a protective antigen-specific memory response in a murine glioma model. PLoS One. 2014:9:e101764.

57. Pilones KA, Kawashima N, Yang AM, Babb JS, Formenti SC, Demaria S. Invariant natural killer T cells regulate breast cancer response to radiation and CTLA-4 blockade. Clin Cancer Res. 2009;15:597-606.

58. Ruocco MG, Pilones KA, Kawashima N, Cammer M, Huang J, Babb JS, et al. Suppressing $T$ cell motility induced by anti-CTLA-4 monotherapy improves antitumor effects. J Clin Invest. 2012:122:3718-30.

59. Golden EB, Chachoua A, Fenton-Kerimian M, Demaria S and Formenti S. Abscopal responses in metastatic non-small cell lung cancer (NSCLC) patients treated on a phase 2 study of combined radiation therapy and 
ipilimumab: evidence for the in situ vaccination hypothesis of radiation [abstract]. Int J Radiat Oncol Biol Phys. 2015; 93:Abstr nr 149.

60. Kwon ED, Drake CG, Scher HI, Fizazi K, Bossi A, van den Eertwegh AJ, et al. Ipilimumab versus placebo after radiotherapy in patients with metastatic castration-resistant prostate cancer that had progressed after docetaxel chemotherapy (CA184-043): a multicentre, randomised, double-blind, phase 3 trial. Lancet Oncol. 2014;15:700-12.

61. Twyman-Saint Victor C, Rech AJ, Maity A, Rengan R, Pauken KE, Stelekati E, et al. Radiation and dual checkpoint blockade activate non-redundant immune mechanisms in cancer. Nature. 2015;520:373-7.

62. Slovin SF, Higano CS, Hamid O, Tejwani S, Harzstark A, Alumkal JJ, et al. Ipilimumab alone or in combination with radiotherapy in metastatic castration-resistant prostate cancer: results from an open-label, multicenter phase I/II study. Ann Oncol. 2013;24:1813-21.

63. Hiniker SM, Reddy SA, Maecker HT, Subrahmanyam PB, Rosenberg-Hasson Y, Swetter SM, et al. A prospective clinical trial combining radiation therapy with systemic immunotherapy in metastatic melanoma. Int J Radiat Oncol Biol Phys. 2016;96:578-88.

64. Tang C, Welsh JW, de Groot P, Massarelli E, Chang JY, Hess KR, et al. Ipilimumab with stereotactic ablative radiation therapy: phase I results and immunologic correlates from peripheral T cells. Clin Cancer Res. 2017;23:1388-96.

65. Shi W, Wuthrick E, Feeney K, Werner-Wasik M, Andrews DW, Evans JJ, et al. Phase I study of ipilimumab with stereotactic radiosurgery for melanoma patients with brain metastases [abstract]. Eur J Cancer. 2014;50:Abstr nr 141.

66. Williams NL, Kim H, Eldredge-Hindy HB, Feeney KJ, Mastrangelo MJ, Sato T, et al. Phase I study of ipilimumab combined with whole-brain radiation therapy or radiosurgery for melanoma patients with brain metastases. Int J Radiat Oncol biol Phys. 2016;96:Abstr nr 1037.

67. Johnson CB, Jagsi R. The promise of the abscopal effect and the future of trials combining immunotherapy and radiation therapy. Int J Radiat Oncol Biol Phys. 2016;95:1254-6.

68. Kang J, Demaria S, Formenti S. Current clinical trials testing the combination of immunotherapy with radiotherapy. J Immunother Cancer. 2016:4:51.

69. Pilon-Thomas S, Mackay A, Vohra N, Mulé JJ. Blockade of PD-L1 enhances the therapeutic efficacy of combination immunotherapy against melanoma. J Immunol. 2010;184:3442-9.

70. Verbrugge I, Gasparini A, Haynes NM, Hagekyriakou J, Galli M, Stewart TJ, et al. The curative outcome of radioimmunotherapy in a mouse breast cancer model relies on mTOR signaling. Radiat Res. 2014;182:219-29.

71. Verbrugge I, Hagekyriakou J, Sharp LL, Galli M, West A, McLaughlin NM, et al. Radiotherapy increases the permissiveness of established mammary tumors to rejection by immunomodulatory antibodies. Cancer Res. 2012;72:3163-74.

72. Zeng J, See AP, Phallen J, Jackson CM, Belcaid Z, Ruzevick J, et al. Anti-PD-1 blockade and stereotactic radiation produce long-term survival in mice with intracranial gliomas. Int J Radiat Oncol Biol Phys. 2013;86:343-9.

73. Hallett WH, Jing W, Drobyski WR, Johnson BD. Immunosuppressive effects of multiple myeloma are overcome by PD-L1 blockade. Biol Blood Marrow Transplant. 2011;17:1133-45.

74. Jing W, Gershan JA, Weber J, Tlomak D, McOlash L, Sabatos-Peyton C, et al. Combined immune checkpoint protein blockade and low dose whole body irradiation as immunotherapy for myeloma. J Immunother Cancer. 2015;3:2.

75. Kearl TJ, Jing W, Gershan JA, Johnson BD. Programmed death receptor-1/ programmed death receptor ligand-1 blockade after transient lymphodepletion to treat myeloma. J Immunol. 2013;190:5620-8.

76. Deng L, Liang $H$, Burnette $B$, Beckett $M$, Darga $T$, Weichselbaum RR, et al Irradiation and anti-PD-L1 treatment synergistically promote antitumor immunity in mice. J Clin Invest. 2014;124:687-95.

77. Pilones KA, Joseph A, Vatner R, Formenti S, Demaria S. Radiation therapy sensitizes a poorly immunogenic breast cancer to PD-1 blockade [abstract]. Int J Radiat Oncol Biol Phys. 2014;90:Abstr nr 121.

78. Aguilera T, Rafat M, Kariolis M, von Eyben R, Graves E, Giaccia A. Tumor immunologic heterogeneity influences response to radiation and combination immunotherapy [abstract]. J Immunother Cancer. 2015;3:Abstr nr P345.

79. Sharabi AB, Nirschl CJ, Kochel CM, Nirschl TR, Francica BJ, Velarde E, et al. Stereotactic radiation therapy augments antigen-specific PD-1-mediated antitumor immune responses via cross-presentation of tumor antigen. Cancer Immunol Res. 2015;3:345-55.
80. Gong X, Li X, Jiang T, Xie H, Zhu Z, Zhou F, et al. Combined radiotherapy and anti-PD-L1 antibody synergistically enhances antitumor effect in nonsmall cell lung cancer. J Thorac Oncol. 2017;12:1085-97.

81. Herter-Sprie GS, Koyama S, Korideck H, Hai J, Deng J, Li YY, et al. Synergy of radiotherapy and PD-1 blockade in Kras-mutant lung cancer. JCI Insight. 2016;1:e87415.

82. Kamdem DT, Steel JC, Wise-Draper T, Kassing WM, Hashemi Sadraei N, Mierzwa ML, et al. Combined radiation and PD-L1 blockade improved tumor control in mouse head and neck squamous cell carcinoma (HNSCC) [abstract]. Int J Radiat Oncol Biol Phys. 2016;94:Abstr nr 248.

83. Rodriguez-Ruiz ME, Rodriguez I, Garasa S, Barbes B, Solorzano JL, PerezGracia JL, et al. Abscopal effects of radiotherapy are enhanced by combined immunostimulatory mAbs and are dependent on CD8 T cells and crosspriming. Cancer Res. 2016;76:5994-6005.

84. Wu CT, Chen WC, Chang YH, Lin WY, Chen MF. The role of PD-L1 in the radiation response and clinical outcome for bladder cancer. Sci Rep. 2016;6:19740.

85. Oh P, Du KL, Leichman L, Aifantis I. PD-1 blockade enhances the efficacy of chemoradiation in a mouse model of esophageal cancer [abstract]. Int J Radiat Oncol Biol Phys. 2016;96:S127-8.

86. Dovedi SJ, Adlard AL, Lipowska-Bhalla G, McKenna C, Jones S, Cheadle EJ, et al. Acquired resistance to fractionated radiotherapy can be overcome by concurrent PD-L1 blockade. Cancer Res. 2014;74:5458-68.

87. Park SS, Dong H, Liu X, Harrington SM, Krco CJ, Grams MP, et al. PD-1 restrains radiotherapy-induced abscopal effect. Cancer Immunol Res. 2015;3:610-9.

88. Dovedi SJ, Cheadle EJ, Popple A, Poon E, Morrow M, Stewart R, et al. Fractionated radiation therapy stimulates anti-tumor immunity mediated by both resident and infiltrating polyclonal T-cell populations when combined with PD1 blockade. Clin Cancer Res 2017: https://doi.org/10.1158/1078-0432. CCR-1116-1673

89. Vanpouille-Box C, Alard A, Aryankalayil MJ, Sarfraz Y, Diamond JM, Schneider $\mathrm{RJ}$, et al. DNA exonuclease Trex1 regulates radiotherapy-induced tumour immunogenicity. Nat Commun. 2017;8:15618.

90. Kim JE, Patel MA, Mangraviti A, Kim ES, Theodros D, Velarde E, et al. Combination therapy with anti-PD-1, anti-TIM-3, and focal radiation results in regression of murine gliomas. Clin Cancer Res. 2017;23:124-36.

91. Wang $X$, Schoenhals JE, Li A, Valdecanas DR, Ye H, Zang F, et al. Suppression of type I IFN signaling in tumors mediates resistance to antiPD-1 treatment that can be overcome by radiotherapy. Cancer Res. 2017;77:839-50

92. Liang H, Deng L, Chmura S, Burnette B, Liadis N, Darga T, et al. Radiationinduced equilibrium is a balance between tumor cell proliferation and $\mathrm{T}$ cell-mediated killing. J Immunol. 2013;190:5874-81.

93. Liang H, Deng L, Hou Y, Meng X, Huang X, Rao E, et al. Host STINGdependent MDSC mobilization drives extrinsic radiation resistance. Nat Commun. 2017:8:1736.

94. Shi L, Chen L, Wu C, Zhu Y, Xu B, Zheng X, et al. PD-1 blockade boosts radiofrequency ablation-elicited adaptive immune responses against tumor. Clin Cancer Res. 2016;22:1173-84

95. Azad A, Yin Lim S, D'Costa Z, Jones K, Diana A, Sansom OJ, et al. PD-L1 blockade enhances response of pancreatic ductal adenocarcinoma to radiotherapy. EMBO Mol Med. 2017:9:167-80.

96. Friedman D, Baird JR, Young KH, Cottam B, Crittenden MR, Friedman S, et al Programmed cell death-1 blockade enhances response to stereotactic radiation in an orthotopic murine model of hepatocellular carcinoma. Hepatol Res. 2017;47:702-14.

97. Kim KJ, Kim JH, Lee SJ, Lee EJ, Shin EC, Seong J. Radiation improves antitumor effect of immune checkpoint inhibitor in murine hepatocellular carcinoma model. Oncotarget. 2017:8:41242-55.

98. Takahashi Y, Yasui T, Tamari K, Minami K, Koizumi M, Seo Y, et al. Radiation combined with checkpoint blockades enhanced antitumor efficacy for osteosarcoma [abstract]. Cancer Res. 2017;77:Abstr nr 4585.

99. Kroon P, Gadiot J, Peeters M, Gasparini A, Deken MA, Yagita H, et al. Concomitant targeting of programmed death-1 (PD-1) and CD137 improves the efficacy of radiotherapy in a mouse model of human BRAFV600-mutant melanoma. Cancer Immunol Immunother. 2016;65:753-63.

100. Xue J, Du S, Lu Y, Dicker A, Lu B. Anti-PD-1 treatment may potentiate the radiation-induced lung injury [abstract].Cancer Res. 2017;77:Abstr nr 3671.

101. Myers CJ, Lu B. Decreased survival after combining thoracic irradiation and an anti-PD-1 antibody is correlated with increased T cell infiltration into 
cardiac and lung tissues. Int J Radiat Oncol Biol Phys. 2017 https://doi.org/ 10.1016/j.jijobp2017.1006.2452.

102. Du S, Zhou L, Shukla G, Wang N, Yang L, Ma X, et al. Pharmacological inhibition of PD-1 exacerbates radiation-induced cardiac toxicity through cytotoxic T cell-mediated myocarditis [abstract]. Int J Radiat Oncol Biol Phys. 2016:96:S88.

103. Haymaker CL, Kim D, Uemura M, Vence LM, Phillip A, McQuail N, et al. Metastatic melanoma patient had a complete response with clonal expansion after whole brain radiation and PD-1 blockade. Cancer Immuno Res. 2017;5:100-5.

104. Alomari AK, Cohen J, Vortmeyer AO, Chiang A, Gettinger S, Goldberg S, et al. Possible interaction of anti-PD-1 therapy with the effects of radiosurgery on brain metastases. Cancer Immunol Res. 2016:4:481-7.

105. Yuan Z, Fromm A, Ahmed KA, Grass GD, Yang GQ, Oliver DE, et al. Radiotherapy rescue of a nivolumab-refractory immune response in a patient with PD-L1 negative metastatic squamous cell carcinoma of the lung. J Thorac Oncol. 2017; https://doi.org/10.1016/j.jtho.2017.1004.1029.

106. Ueki K, Kosaka Y, Kimino G, Imagumbai T, Takayama K, Kokubo M. Treatment of malignant melanoma with nivolumab and vemurafenib combined with hypofractionated radiation therapy. International Cancer Conference Journal. 2016:5:214-8.

107. Sharabi A, Kim SS, Kato S, Sanders PD, Patel SP, Sanghvi P, et al. Exceptional response to nivolumab and stereotactic body radiation therapy (SBRT) in neuroendocrine cervical carcinoma with high tumor mutational burden: management considerations from the center for personalized cancer therapy at UC san Diego Moores Cancer center. Oncologist. 2017;22:631-7.

108. Takamori S, Toyokawa G, Takada K, Shoji F, Okamoto T and Maehara Y. Combination therapy of radiotherapy and anti-PD-1/PD-L1 treatment in non-small cell lung cancer, a mini-review. Clin Lung Cancer 2017: https:// doi.org/10.1016/j.cllc.2017.1006.1015.

109. Alevizakos M, Ollila DW, Chera BS, Dodd LG, Kish JB, Moschos SJ. Combined modality neoadjuvant treatment for stage III/V melanoma with PD-1 blockade plus radiation: a case series. Cancer Treatment and Research Communicatons. 2017;10:12-6.

110. Michot JM, Mazeron R, Dercle L, Ammari S, Canova C, Marabelle A, et al. Abscopal effect in a Hodgkin lymphoma patient treated by an antiprogrammed death 1 antibody. Eur J Cancer. 2016;66:91-4.

111. Xie G, Gu D, Zhang L, Chen S and Wu D. A rapid and systemic complete response to stereotactic body radiation therapy and pembrolizumab in a patient with metastatic renal cell carcinoma. Cancer Biol Ther 2017: https:// doi.org/10.1080/15384047.15382017.11345389.

112. LaPlant Q, Deselm C, Lockney NA, Hsieh J and Yamada Y. Potential abscopal response to dual checkpoint blockade in RCC after reirradiation using dosepainting SBRT. Pract Radiat Oncol 2017: https://doi.org/10.1016/j.prro.2017. 1004.1009.

113. Ahmed KA, Abuodeh YA, Echevarria Ml, Arrington JA, Stallworth DG, Hogue $C$, et al. Clinical outcomes of melanoma brain metastases treated with stereotactic radiosurgery and anti-PD-1 therapy, anti-CTLA-4 therapy, BRAF/ MEK inhibitors, BRAF inhibitor, or conventional chemotherapy. Ann Oncol. 2016:27:2288-94.

114. Ahmed KA, Stallworth DG, Kim Y, Johnstone PA, Harrison LB, Caudell JJ, et al. Clinical outcomes of melanoma brain metastases treated with stereotactic radiation and anti-PD-1 therapy. Ann Oncol. 2016;27:434-41.

115. Olson AC, Patel K, Mowery YM, Wynne J, Ready N, Kirkpatrick JP, et al. AntiPD-1 therapy and stereotactic radiation for melanoma and non-small cell lung cancer patients with brain metastases: a 2-institution series [abstract] Int J Radiat Oncol Biol Phys. 2016; 96:Abstr nr 2238

116. Liniker E, Menzies AM, Kong BY, Cooper A, Ramanujam S, Lo S, et al. Activity and safety of radiotherapy with anti-PD-1 drug therapy in patients with metastatic melanoma. Oncoimmunology. 2016;5:e1214788.

117. Qian JM, Yu JB, Kluger HM, Chiang VL. Timing and type of immune checkpoint therapy affect the early radiographic response of melanoma brain metastases to stereotactic radiosurgery. Cancer. 2016;122:3051-8.

118. Bledsoe TJ, Rutter CE, Lester-Coll NH, Bi X, Decker RH. Radiation to oligoprogessive sites of disease can prolong the duration of response to immune checkpoint inhibitors in patients with metastatic non-small cell lung cancer [abstract]. Int J Radiat Oncol Biol Phys. 2016:96:Abstr nr 3178

119. Roger A, Finet A, Boru B, Mazeron JJ, Otmezguine Y, Blom A, et al. Efficacy of combined hypofractionated radiotherapy and anti-PD-1 monotherapy in patients with melanoma [abstract]. J Clin Oncol. 2017;35:Abstr nr e21008.
120. Pike LRG, Bang A, Ott P, Balboni T, Taylor A, Catalano P, et al. Radiation and PD-1 inhibition: favorable outcomes after brain-directed radiation. Radiother Oncol. 2017; https://doi.org/10.1016/.j.radonc.2017.1006.1006.

121. Shaverdian N, Lisberg AE, Bornazyan K, Veruttipong D, Goldman JW, Formenti SC, et al. Previous radiotherapy and the clinical activity and toxicity of pembrolizumab in the treatment of non-small-cell lung cancer: a secondary analysis of the KEYNOTE-001 phase 1 trial. Lancet Oncol. 2017;18:895-903.

122. Choong ES, Lo S, Drummond M, Fogarty GB, Menzies AM, Guminski A, et al. Survival of patients with melanoma brain metastasis treated with stereotactic radiosurgery and active systemic drug therapies. Eur J Cancer. 2017;75:169-78.

123. Wilhite TJ, Chandra RA, Balboni TA, Taylor A, Aizer AA, Spektor A, et al. Toxicity profile of contemporaneous PD-1 inhibitor immunotherapy and radiotherapy [abstract]. Cancer Res. 2016;76:Abstr nr 4989.

124. von Reibnitz D, Wu AJ, Barker CA, Panchoo K, Rimner A. Safety of combining immune checkpoint inhibition and thoracic radiation therapy [abstract]. Int J Radiat Oncol Biol Phys. 2016;96:Abstr nr 351.

125. Ahmed KA, Grass GD, Creelan B, Gray J, Kim S, Dilling TJ, et al. Tolerability and safety of thoracic radiation and immune checkpoint inhibitors among patients with lung cancer [abstract]. Int J Radiat Oncol Biol Phys. 2017;98:Abstr nr 10.

126. Shibaki R, Akamatsu H, Fujimoto M, Koh Y, Yamamoto N. Nivolumab induced radiation recall pneumonitis after two years of radiotherapy. Ann Oncol. 2017;28:1404-5

127. Bang A, Wilhite TJ, Pike LRG, Cagney DN, Aizer AA, Taylor A, et al. Multicenter evaluation of the tolerability of combined treatment with PD-1 and CTLA-4 immune checkpoint inhibitors and palliative radiation therapy. Int J Radiat Oncol Biol Phys. 2017;98:344-51.

128. Ahmed KA, Kim S, Arrington J, Naghavi AO, Dilling TJ, Creelan BC, et al. Outcomes targeting the PD-1/PD-L1 axis in conjunction with stereotactic radiation for patients with non-small cell lung cancer brain metastases. J Neuro-Oncol. 2017; https://doi.org/10.1007/s1 1060-11017-12437-11065.

129. Fang P, Jiang W, Allen P, Glitza I, Guha N, Hwu P, et al. Radiation necrosis with stereotactic radiosurgery combined with CTLA-4 blockade and PD-1 inhibition for treatment of intracranial disease in metastatic melanoma. J Neuro-Oncol. 2017; https://doi.org/10.1007/s11060-11017-12470-11064.

130. Colaco RJ, Martin P, Kluger HM, Yu JB, Chiang VL. Does immunotherapy increase the rate of radiation necrosis after radiosurgical treatment of brain metastases? J Neurosurg. 2016;125:17-23.

131. Kiess AP, Wolchok JD, Barker CA, Postow MA, Tabar V, Huse JT, et al. Stereotactic radiosurgery for melanoma brain metastases in patients receiving ipilimumab: safety profile and efficacy of combined treatment. Int J Radiat Oncol Biol Phys. 2015;92:368-75.

132. Patel KR, Shoukat S, Oliver DE, Chowdhary M, Rizzo M, Lawson DH, et al. Ipilimumab and stereotactic radiosurgery versus stereotactic radiosurgery alone for newly diagnosed melanoma brain metastases. Am J Clin Oncol. 2015: https://doi.org/10.1097/COC.0000000000000199.

133. Kaidar-Person O, Zagar TM, Deal A, Moschos SJ, Ewend MG, Sasaki-Adams D, et al. The incidence of radiation necrosis following stereotactic radiotherapy for melanoma brain metastases: the potential impact of immunotherapy. Anti-Cancer Drugs. 2017;28:669-75.

134. Sagiv-Barfi I, Rajapaksa A, Czerwinski D, Chang S, Hebb J, Chester C, et al. Local tumor irradiation combined with a-PDL-1 immune checkpoint inhibition results in local and systemic anti-tumor responses: successful translation of a mouse model to a human case series [abstract]. Cancer res. 2014;74:Abstr nr 2941.

135. Barker CA, Postow MA, Kronenberg SA, Ma J, Yamada Y, Beal K, et al. Concurrent radiation therapy (RT), ipilimumab (Ipi) and/or nivolumab (nivo) on a phase 1 clinical trial [abstract]. Int J Radiat Oncol biol Phys. 2015;93:Abstr nr 1133.

136. Levy A, Massard C, Soria JC, Deutsch E. Concurrent irradiation with the antiprogrammed cell death ligand-1 immune checkpoint blocker durvalumab: single Centre subset analysis from a phase 1/2 trial. Eur J Cancer. 2016;68:156-62

137. Duffy AG, Makarova-Rusher OV, Kleiner DE, Alewine C, Figg WD, Steinberg $S M$, et al. A pilot study of immune checkpoint inhibition in combination with radiation therapy in patients with metastatic pancreatic cancer [abstract]. J Clin Oncol. 2017;35:Abstr nr e15786.

138. Lin SH, Lin Y, Price J, Parker M, Gomez DR, Welsh JW, et al. DETERRED: PD-L1 blockade to evaluate the safety of lung cancer therapy using carboplatin, 
paclitaxel, and radiation combined with MPDL3280A (atezolizumab) [abstract]. J Clin Oncol. 2017;35:Abstr nr 3064.

139. Antonia SJ, Villegas A, Daniel D, Vicente D, Murakami S, Hui R, et al. Durvalumab after chemoradiotherapy in stage III non-small-cell lung cancer. N Engl J Med 2017:doi:https://doi.org/10.1056/NEJMoa1709937.

140. Lee $Y$, Auh SL, Wang Y, Burnette B, Wang Y, Meng Y, et al. Therapeutic effects of ablative radiation on local tumor require CD8+ T cells: changing strategies for cancer treatment. Blood. 2009;114:589-95.

141. Lugade AA, Moran JP, Gerber SA, Rose RC, Frelinger JG, Lord EM. Local radiation therapy of B16 melanoma tumors increases the generation of tumor antigen-specific effector cells that traffic to the tumor. J Immunol. 2005;174:7516-23.

142. Twyman-Saint Victor C, Rech A, Maity A, Rengan R, Pauken K, Stelekati E, et al. Mechanisms of tumor response and resistance to radiation and dual checkpoint blockade in mice and patients [abstract]. Cancer Immunol Res. 2016:4:Abstr nr A056

143. Schaue D, Ratikan JA, Iwamoto KS, McBride WH. Maximizing tumor immunity with fractionated radiation. Int J Radiat Oncol Biol Phys. 2012;83:1306-10

144. Dovedi SJ, Illidge TM. The antitumor immune response generated by fractionated radiation therapy may be limited by tumor cell adaptive resistance and can be circumvented by PD-L1 blockade. Oncoimmunology. 2015:4:e1016709.

145. Yoon SM, Shaikh T, Hallman M. Therapeutic management options for stage III non-small cell lung cancer. World J Clin Oncol. 2017;8:1-20.

146. Eggermont AM, Chiarion-Sileni V, Grob JJ, Dummer R, Wolchok JD, Schmidt $\mathrm{H}$, et al. Prolonged survival in stage III melanoma with ipilimumab adjuvant therapy. N Engl J Med. 2016;375:1845-55.

147. Luke JJ, Lemons JM, Karrison TG, Pitroda SP, Melotek JM, Zha Y, et al. Safety and clinical activity of pembrolizumab and multisite stereotactic body radiotherapy in patients with advanced solid tumors. J Clin Oncol 2018: https://doi.org/10.1200/JCO2017.1276.2229.

148. Monjazeb AM, Schoenfeld JD. Radiation dose and checkpoint blockade immunotherapy: unanswered questions. Lancet Oncol. 2016;17:e3-4.

149. Alexander GS, Palmer JD, Tuluc M, Lin J, Dicker AP, Bar-Ad V, et al. Immune biomarkers of treatment failure for a patient on a phase I clinical trial of pembrolizumab plus radiotherapy. J Hematol Oncol. 2016;9:96.

150. Wu CJ, Tsai YT, Chang CC, Lee IJ, Wu PY, Tao MH. Efficacy of combining radiotherapy and immunotherapy for metastatic colorectal cancer and the modulation of tumor [abstract]. J Immunol. 2017;198:79.15.

151. Vermeer DW, Powell S, Spanos WC, Lee JH. PD-1 blockade synergizes with cisplatin radiation therapy aiding in clearance of murine HPV+ oropharyngeal carcinoma [abstract]. Cancer Immunol Res. 2015;3:Abstr nr A55.

152. Nambiar DK, Aguilera T, Bloomstein JD, Cao H, Koong A, Le QT. Targeting galectin-1 in combination with radiation and immune checkpoint therapy in head and neck cancers [abstract]. Cancer Res. 2017;77:Abstr nr LB-180.

153. Budhu S, De Henau O, Zappasodi R, Giese R, Campesato LF, Barker C, et al. Phosphatidylserine targeting antibody in combination with tumor radiation and immune checkpoint blockade promotes anti-tumor activity in mouse B16 melanoma [abstract]. Cancer Res. 2017;77:Abstr nr 574.

154. Zheng W, Skowron KB, Namm JP, Burnette B, Fernandez C, Arina A, et al. Combination of radiotherapy and vaccination overcomes checkpoint blockade resistance. Oncotarget. 2016;7:43039-51.

155. Walker AJ, Nirscle CJ, Nugent K, Nirschle TR, Harris TJ, Wang H, et al. Combining checkpoint blockade with radiation therapy results in tumor and immunological responses in an autochthonous mouse model of lung cancer [abstract]. Int J Radiat Oncol Biol Phys. 2014;90:Abstr nr 117.

156. Kent CL, Mowery YM, Wisdom AJ, Van Mater D, Castle KD, Reddy A, et al. Immune checkpoint inhibition and radiation therapy in 2 primary mouse models of soft tissue sarcoma: impact of tumor mutational load [abstract]. Int J Radiat Oncol Biol Phys. 2016;96:Abstr nr 3418.

157. Wang S, Kuczma M, Pi W, Kong V, Campbell J, Jin JY, et al. Combined stereotactic body radiation therapy and immunotherapy on $4 \mathrm{~T} 1$ triplenegative breast cancer murine model [abstract]. Int J Radiat Oncol Biol Phys. 2016:96:Abstr nr 3429.

\section{Ready to submit your research? Choose BMC and benefit from:}

- fast, convenient online submission

- thorough peer review by experienced researchers in your field

- rapid publication on acceptance

- support for research data, including large and complex data types

- gold Open Access which fosters wider collaboration and increased citations

- maximum visibility for your research: over $100 \mathrm{M}$ website views per year

At BMC, research is always in progress.

Learn more biomedcentral.com/submissions 